\title{
Age and Sources of Metasedimentary Rocks of the Galam Terrane in the Mongol-Okhotsk Fold Belt: Results of U-Pb Age and Lu-Hf Isotope Data from Detrital Zircons
}

\author{
V. A. Zaika ${ }^{a, *}$ and A. A. Sorokin ${ }^{a}$ \\ ${ }^{a}$ Institute of Geology and Nature Management, Far East Branch, Russian Academy of Sciences, \\ Blagoveshchensk, 675000 Russia \\ *e-mail: zaika_v_a_88@mail.ru
}

Received March 15, 2021; revised June 24, 2021; accepted August 24, 2021

\begin{abstract}
The Mongol-Okhotsk fold belt is one of the major structural elements of East Asia. In this article, we present $\mathrm{U}-\mathrm{Pb}$ age and $\mathrm{Hf}$ isotope data for detrital zircons from metasedimentary rocks of the Galam Terrane. Our new data confirm that these rocks contain a significant amount of Archean and Paleoproterozoic zircons: most grains, regardless of age, have negative $\varepsilon_{\mathrm{Hf}(\mathrm{t})}$ values from -30.0 to -10.0 and model age $t_{\mathrm{Hf}(\mathrm{C})}>2.2 \mathrm{Ga}$. The main sources of detrital material for the metasedimentary rocks of the Galam Terrane were igneous and metamorphic complexes of the southeastern margin of the Siberian Craton. Some of the Devonian and Carboniferous zircons have slightly negative and positive $\varepsilon_{\mathrm{Hf}(\mathrm{t})}$ values of -7.4 to +6.9 and younger $t_{\mathrm{Hf}(\mathrm{C})}$ ages of $1.46-0.90 \mathrm{Ga}$. These zircons were derived from eroded island arcs in the Mongol-Okhotsk Paleocean. Our results suggest that the Galam Terrane is a Paleozoic accretionary complex of the Siberian Craton.
\end{abstract}

Keywords: detrital zircon, U-Pb and Hf isotope data, provenance, Mongol-Okhotsk Paleocean, Galam Terrane DOI: $10.1134 / \mathrm{S} 001685212106008 \mathrm{X}$

\section{INTRODUCTION}

The Mongol-Okhotsk fold belt is one of the main structural elements of East Asia and is probably the youngest orogenic belt within the Central Asian fold belt [74, 85]; it stretches for more than $3000 \mathrm{~km}$ northeast of central Mongolia through northern Mongolia, northeastern China, and eastern Russia to the Sea of Okhotsk (Fig. 1). At present, it is assumed that the Mongol-Okhotsk belt is a relic of the ocean of the same name, the closing of which occurred from west to east during collision of the Amur Superterrane and the margin of the Siberian Craton [33, 51, 71, 74, 75, 85].

The modern structural plan of the MongolOkhotsk belt is a complex collage of numerous fusiform tectonic blocks, which are probably fragments of accretionary wedges [33, 51, 59]. Paleozoic suprasubduction ophiolite and gabbro-granite bodies located in the Mongol-Okhotsk belt, as well as Paleozoic and Mesozoic intrusions in its southern and northern frames, indicate repeat subduction processes in the northern and southern directions (in modern coordinates) during its formation $[2-4,6-8,19,23$, $27,29,30,33,34,38,47,51,54,69-71,74,82]$. However, many aspects in the evolution of the MongolOkhotsk belt remain unclear, including the timing and mechanisms of accretion and collision processes.
One of the keys to tectonic reconstruction of the Mongol-Okhotsk belt is systematic $\mathrm{U}-\mathrm{Pb}$ geochronological and $\mathrm{Lu}-\mathrm{Hf}$ isotope studies of detrital zircons. Such data make it possible to determine the lower age limit of sedimentation, as well as to characterize the age of detrital material and its source. Sedimentary deposits of the Mongol-Okhotsk belt, as a rule, are depleted in fossil flora and fauna, and therefore, geochronological data for detrital zircons are the main source of information on the age of these deposits [33, 51].

$\mathrm{U}-\mathrm{Pb}$ and $\mathrm{Lu}-\mathrm{Hf}$ isotope studies were performed for some objects of the Adaatsag, Doshgol, KhangaiKhentei, and Erendav terranes of the western part of the Mongol-Okhotsk belt, as well as in combination with $\mathrm{Sm}-\mathrm{Nd}$ studies for objects of the Yankan, Tukuringra, Un'ya-Bom, and Dzhagdy terranes in the eastern part of the belt $[22,46,49,50,62,66]$. The results of these studies show that in the structure of the Yankan terrane, metasedimentary rocks belonging to accretionary complexes formed above subduction zones with different polarities are spatially superposed [69]. It is assumed that one accretionary complex was formed in the Paleozoic in front of the southeastern margin of the Siberian Craton, and the other, in front of the northern margin of the Amur Superterrane. The similar interpretation was proposed for metasedimentary 

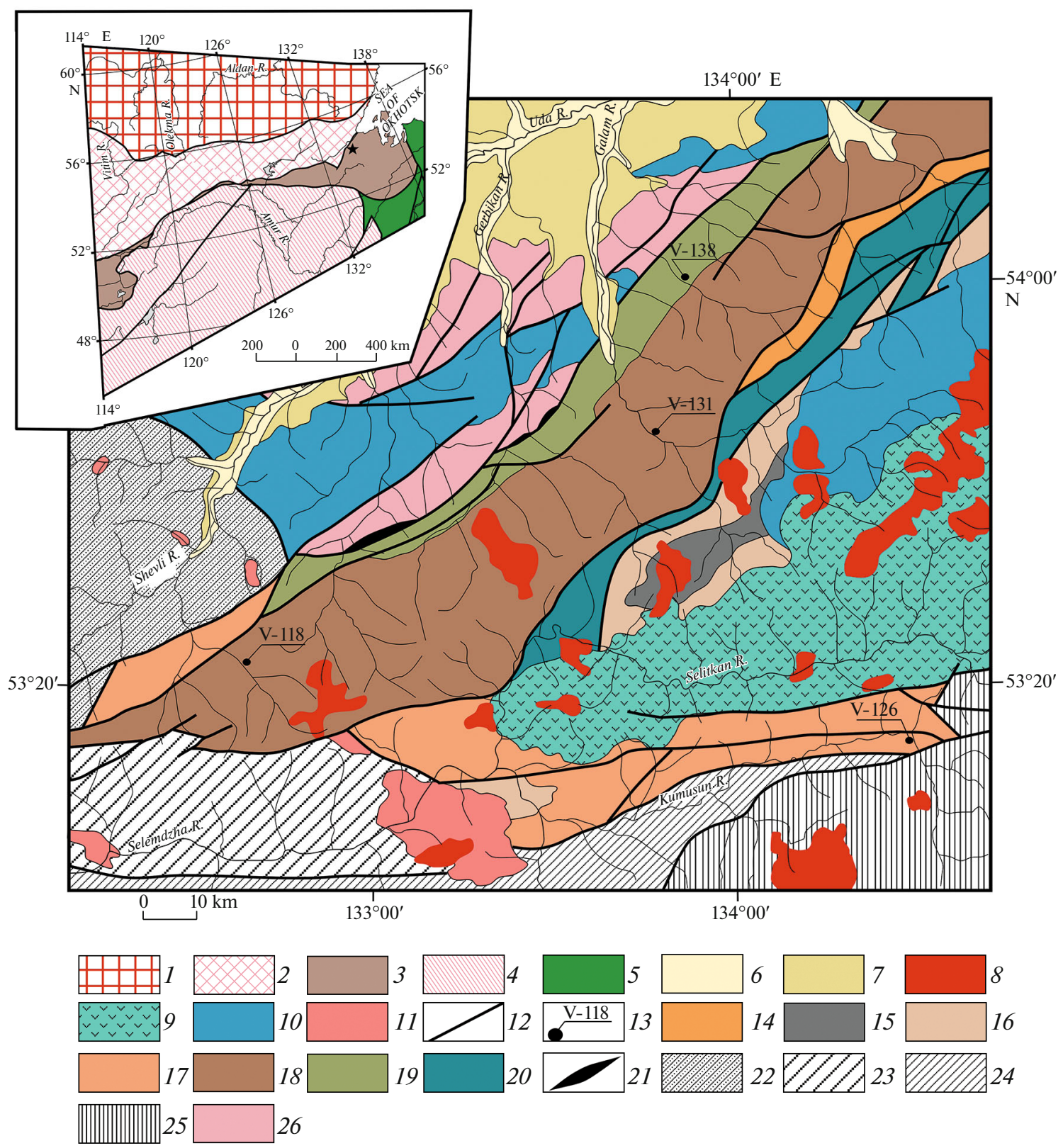

Fig. 1. Geological sketch map of Galam Terrane (compiled after [20] with changes and additions). Asterisk denotes study area. Inset: tectonic sketch map of Mongol-Okhotsk belt and main structures of East Asia (compiled after [33], with changes and additions). 1, Siberian Craton; 2, collage of terranes of southeastern frame of Siberian Craton; 3, Mongol-Okhotsk fold belt; 4, Amur Superterrane; 5, Sikhote-Alin orogenic belt; 6-7, deposits: 6, Holocene; 7, Pleistocene; 8, Early Cretaceous granites; 9, Late Cretaceous volcanics; 10, Late Triassic-Jurassic, Early Cretaceous sedimentary rocks; 11, Permian granites; 12, major faults; 13, sampling sites; 14-20, sedimentary formation of the Galam Terrane: 14, Permian, 15, Early Carboniferous; 16, Late Devonian; 17, Middle, Middle-Late Devonian; 18, Early, Early-Middle Devonian; 19, Early Silurian; 20, Cambrian; 21, Early Paleozoic granites; 22-25, adjacent (bordering) terranes: 22, Lan; 23, Tokur, 24, Selemdzha; 25, Ul'ban; 26, Late Mesozoic formations of southern frame of Siberian Craton.

rocks of the western part of the Mongol-Okhotsk belt $[46,50]$. Also, U-Pb geochronological data led to the conclusion that metasedimentary rocks of the Tukuringra and Dzhagdy terranes are of Mesozoic age, not Paleozoic, as previously assumed, and they are a fragment of the Early Mesozoic accretionary complex in front of the margin of the Amur Superterrane $[22,36,66]$.
Thus, the results of $\mathrm{U}-\mathrm{Pb}, \mathrm{Lu}-\mathrm{Hf}$ isotope studies of detrital zircons from weakly metamorphosed sedimentary complexes of the Mongol-Okhotsk belt, in addition to widespread intrusive rocks along the northern and southern continental frames of the belt (in modern coordinates), suggest that the MongolOkhotsk ocean hosted subduction zones of opposite polarity in the Paleozoic and Mesozoic. To confirm 
this assumption, we carried out $\mathrm{U}-\mathrm{Pb}$ geochronological and $\mathrm{Lu}-\mathrm{Hf}$ isotope studies of detrital zircons in Paleozoic metasedimentary rocks of the Galam Terrane in order to determine the age, provenance areas of terrigenous material, and tectonic nature of this terrane (Fig. 1). Because the Galam Terrane is one of the largest of the Mongol-Okhotsk orogenic belt, these data are a key for understanding the evolutionary history of the entire belt.

\section{STRUCTURE OF THE GALAM TERRANE}

The Galam Terrane is wedge-shaped (Fig. 1). In the northwest, it borders the Dzhugdzhur-Stanovoy superterrane of the southern margin of the Siberian Craton and is separated along the Uligdan fault zone from the Lan terrane of the Mongol-Okhotsk belt. In the south and southeast, the Galam terrane along the Mariinsk and Tugur fault systems borders on the Tokur, Selemdza, and Ul'ban terranes of the Mongol-Okhotsk belt. The structure of the Galam Terrane includes weakly metamorphosed terrigenous deposits, metabasalts, and limestones from the Early Cambrian to the Late Permian. According to geological mapping, the Galam Terrane consists of several structural

Fig. 2. Stratigraphic core of studied sedimentary deposits (compiled after [20] with changes and additions). International stratigraphic scale was used (after [86]). Asterisk denotes sampling site. $\mathrm{P}_{1-2} \mathrm{nk}$, Nel'kan group: metasandstones, metasiltstones, gravelstones; $\mathrm{C}_{1} \mathrm{tm}$, Torom-Makit Formation: metasandstones, metasiltstones; $\mathrm{C}_{1}$ mš, MaloShantar Formation: metasandstones, metasiltstones; $\mathrm{C}_{1} \mathrm{čm}$, Chumavrin Formation: metasandstones, metasiltstones, metabasalts; $\mathrm{C}_{1} \mathrm{~lm}$, Lam Formation: metabasalts, jaspers; $\mathrm{C}_{1}$ lč, Levochumavrin Formation: metasandstones, metasiltstones; $\mathrm{D}_{3} \mathrm{kv}$, Kovakh Formation: metasandstones, gravelstones; $\mathrm{D}_{3} \mathrm{kr}$, Korel Formation: metasiltstones, metabasalts; $\mathrm{D}_{3} \lg$, Lindgol'm Formation: metasandstones, metasiltstones, metabasalts; $\mathrm{D}_{3} \mathrm{mk}$, Maksin Formation: metasandstones, metasiltstones; $\mathrm{D}_{2-3} \mathrm{~nm}$, Nimi Formation: metasandstones, metasiltstones, metabasalts; $\mathrm{D}_{2} \mathrm{vn}$, Vnutrennii Formation: metasandstones, metasiltstones, metabasalts; $\mathrm{D}_{2} \mathrm{ak}$, Akrinda Formation: metasandstones, metasiltstones; $\mathrm{D}_{2}$ it, Itmata Formation: metasandstones, metasiltstones; $\mathrm{D}_{1-2} \mathrm{tk}$, Taikan Formation: metasandstones, metasiltstones; $\mathrm{D}_{1}$ ? el, Elgakan Formation: jasper, metabasalt, mudstone; $\mathrm{D}_{1}$ on, Onnetock Formation: metasandstones, metasiltstones, jasper; $\mathrm{D}_{1}$ ig, Ir-Galam Formation: jaspers, metabasalts, mudstones; $\mathrm{D}_{1} \mathrm{ml}$, Molukan Formation: metasandstones, metasiltstones, mudstones; $\mathrm{D}_{1}$ gr, Gerbikan Formation: metasandstones, metasiltstones, mudstones; $\mathrm{D}_{1} \mathrm{br}$, Borollak Formation: metasandstones, metasiltstones; $\mathrm{S}_{2}$ ?kn, Kunnikit Formation: jasper, mudstones, metasiltstones; $\mathrm{S}_{1-2} \mathrm{dž}$, Dzhyalak Formation: jasper, metabasalts, metasandstones, metasiltstones; $\mathrm{S}_{1}$ ?tl, Tylakchan Formation: mudstones, jaspers, metabasalts; $\mathrm{S}_{1} \lg$, Lagap Formation: metabasalts, metasandstones; $\mathrm{S}_{1}$ bg, Burgali Formation: metabasalts, metasandstones; $E_{3}$ ?ir, Ir Formation: jaspers, metabasalts, mudstones; $E_{2-3} d z ̌$, Dzhavodi Formation: limestones, jaspers, metabasalts; $\epsilon_{1-2} t$, Ty'lsk Formation: limestones; $\epsilon_{1-2} \mathrm{kr}$, Kurum Formation: jasper, mudstone, metabasalt; $\mathrm{E}_{1}$ ut, Ust'-Tok Formation: jasper, mudstones, metabasalts; $\mathrm{E}_{1}$ mut, Maloutonak Formation: limestones, metasandstones, metasiltstones.

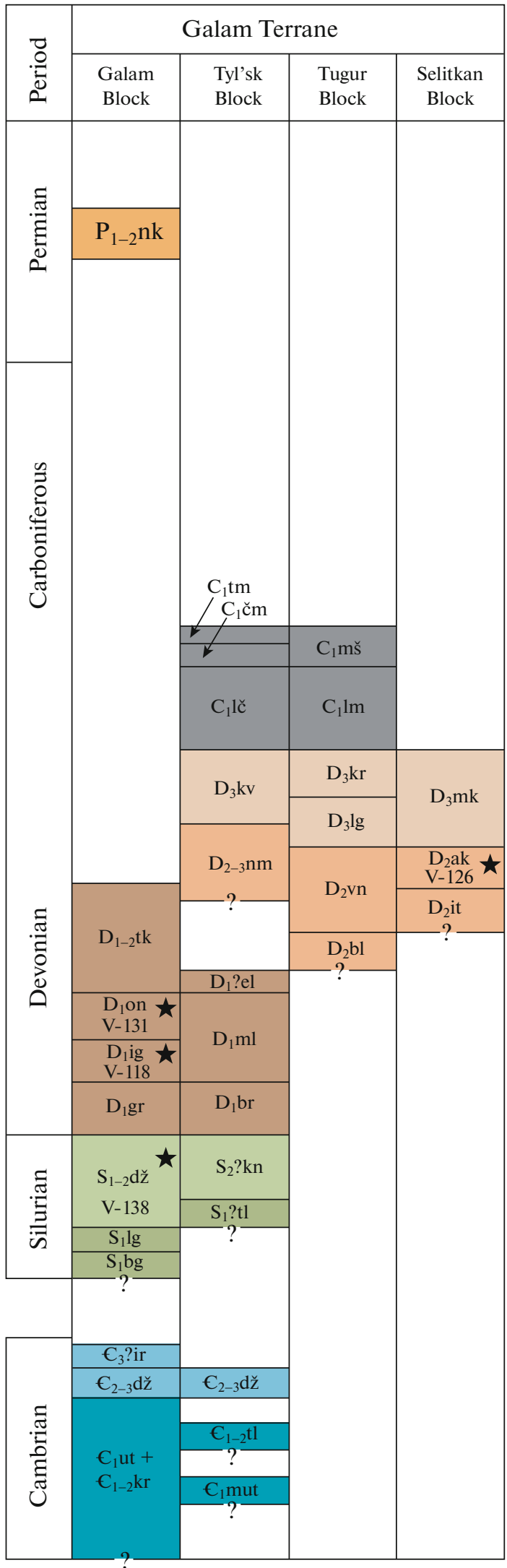


zones or tectonic blocks: the Galam, Tyl'sk, Tugur, and Selitkan blocks [16] (Fig. 2).

The most ancient in the Galam Terrane are the Maloutannak (2900 m), Dzhavodi (1800 m), Ust'-Tok (1400 m), Ir (1250 m), Kurum (450 m), and the Tyl'sk $(390 \mathrm{~m})$ formations, which are mainly represented by siliceous rocks, metabasalts, fine-grained sandstones and siltstones, and limestones (Fig. 2). According to V.Yu. Zabrodin et al. [20], limestones contain a diverse Cambrian fauna of archaeocyathids (Ladaecyathus sp., Erbocyathidae gen. et sp. indet., Tumuliolynthus sp., Capsulocyathus (?), Fransuasaecyathus sp. indet., Ajacicyathus sp., Nochoroicyathus lenaicus Zhuravl., Tumuliolynthus sp., Archaeolynthus sp.); trilobites (Alokistocare? sp. nov., Ptychoporiidae gen. et sp. nov., Glyptagnostus ex gr. reticulatus); and brachiopods (Obolella aff. chromatica Billings., Lingulella minuscula Sob., Acrothele horida Sob., Dictyonina hexagona Bell., Acrotretidae den. et sp. indet., Angulotreta triangularis Palmer, Opisthotretadepressa Palmer). Cambrian radiolarians Polyentactinia dzhagdiensis Naz. and Entactinia iriensis Naz. have been found in cherts.

The Silurian Burgali (2600 m), Tylakchan (2250 m), Lagap (1910 m), Dzhyalak (1200 m), and Kunnikit $(500 \mathrm{~m})$ formations are lithologically close to Cambrian deposits (Fig. 2). Terrigenous rocks contain corals Palaeofavosites alveolaris (Goldf.), Multisolenia tortuosa Fritz., Multisolenia ninae (Tchern.), Favosites gothlandicus Lam., Miculiella annae Ivnsk., brachiopods Eospiriferradiatus (Sow.), Clorinda substantiva Kulk., and Protatrypa septentrionalis (Nikif.) [20].

The Devonian Gerbikan (4240 m), Ir-Galam (3590 m), Onnetock (3100 m), Nimi (2900 m), Korel $(2800 \mathrm{~m})$, Taikan $(2530 \mathrm{~m})$, Molukan (2360 m), Imata (2125 m), Elkagan (1620 m), Kovakh (1525 m), Borollak $(1500 \mathrm{~m})$, and Maksin $(1200 \mathrm{~m})$, formations, as well as the Akrinda (to $5000 \mathrm{~m}$ ) and Cape Vnutrenniy $(2100 \mathrm{~m})$ formations, are represented by sandstones, siltstones, clay shale, calcareous rocks, jasper, and basalts (Fig. 2).

Sedimentary rocks contain plant remains and spore-pollen complexes of Taeniocrada cf. decheniana (Goepp.) Kr. et W., Drepanophycus spinaeformis Goepp., D. cf. gaspianus (Daws.) Stock., Eogaspesiea gracilis Dab., Psilophyton cf. princers Daws., Aphyllopteris sp., Dicranophyton sp., Dawsonites sp., Protolepidodendron $\mathrm{cf}$. scharyanum Kr., P. protolepidodendron scharyanum Kr., Aneurophyton germanicum Kr. et $\mathrm{W}$. Various stromatoporoid complexes were found in limestones: Stromatopora boiarschinoi J. a vor., Simhlexodictyon coninconicum Khrom., Tabulata Corolites sp., Pachyfavosites sp., Oculipora sp., Alveolites sp., Alveolitella sp., Crassialveolites aff. crassus (Les.), Placacoenjenites ex gr. orientalis Eichw., Bryozoan Semicoscinium ravkovskii Nekh., S. granifeerum (Hall), Fenestella vera Ulrich., Atrypa devoniana descrescens F. et F., A. matutinalis Khud., Vagrania kolymensis (Nal.) V. cf. kolymensis (Nal.) Var. intermediafera (Khud.), V. (Mina- trypa) flabellata (Roem.), Lasutkina sp., crinoids Cupressocrinites cf. minor Yelt., C.gracilis Goldf., Mediocrinus cf. medius (Yelt.), M. persimilis (I. Dubat.), Pentagonacyclicus petrovensis Schisch [20].

The Lower Carboniferous Chumavrin (3500 m), Levochumavrin $(2750 \mathrm{~m})$, Lam $(1600 \mathrm{~m})$, MaloShantar $(1200 \mathrm{~m})$, Torom-Makit $(800 \mathrm{~m})$, as well as Devonian formations, are represented by terrigenouscarbonate and volcanogenic-siliceous (jasper) rocks (Fig. 2). Siltstones and limestones contain bryozoans Rhombopora sp., Nikiforovella sp., Sulcoretepora aff. astepnata Nekh., Fenestella sp. (aff. F. rudis Ulr.), Crinoids Platycrinites (?) texanum (M. et Jeff.), Pentagonocyclicus priscus Sfuk. The following conodonts have been established in jasper: Siphonodella cf. obsoleta Hass., Polygnathus ex gr. inornatus Br. et M., Siphonodella sp. aff. S. crenulata (Cooper), S. sp. aff. S. lobata (Br. Et M.), S. sp. aff. S. sulcata (Huddle), Scaliognothus cf. anchoralis Br. et. M [20].

The Permian Nel'kan (3650 m) group consists of coarse-grained terrigenous sediments containing bivalvia Neoschizodus sp., Chaenomya (?) sp., Edmondia (?) sp., Angarian flora Paracalamites cf. vicinalis Radcz., P. cf. angustus Such., Noegaerathiopsis cf. derzavini Neub., N. tschirkovae Zal [20] (Fig. 2).

Plagiogranite intrusions occur along the Uligdan Fault, which separates the Galam Terrane from the metamorphic complexes of the southern margin of the Siberian Craton (Fig. 1). On the modern geological map, these rocks are attributed to the Lower Devonian (?) Maloelga Complex [20]. According to Sun et al. [67], plagiogranites are of Cambrian age (511 $\pm 3 \mathrm{Ma}$, U-Pb method based on zircons).

Upper Cretaceous granitoids and volcanic rocks are widespread within the Galam Terrane (Fig. 1). They formed after closing of the Mongol-Okhotsk belt and are associated with tectonic processes along the Pacific margin of Asia.

The concepts of the geodynamic nature of the Galam Terrane are significantly different. B.A. Natal'in [32] believed that the Galam Terrane is an accretionary complex of the Siberian Craton, which is a complex thrust structure. In the structure of the terrane, he identified three rock associations:

— basalts and siliceous rocks;

- terrigenous-layered deposits;

- olistostromes.

It was shown that these rock associations make up separate tectonic plates, but they do not form a single sedimentary formation [32]. A.I. Khanchuk [15, 51] proposed a model according to which the Galam Terrane is a displaced fragment of the Okhotsk-Koryak orogenic belt, not a component of the MongolOkhotsk belt. This model is based on the similarity of the Cambrian fauna of the Galam Terrane and Okhotsk-Koryak belt. 

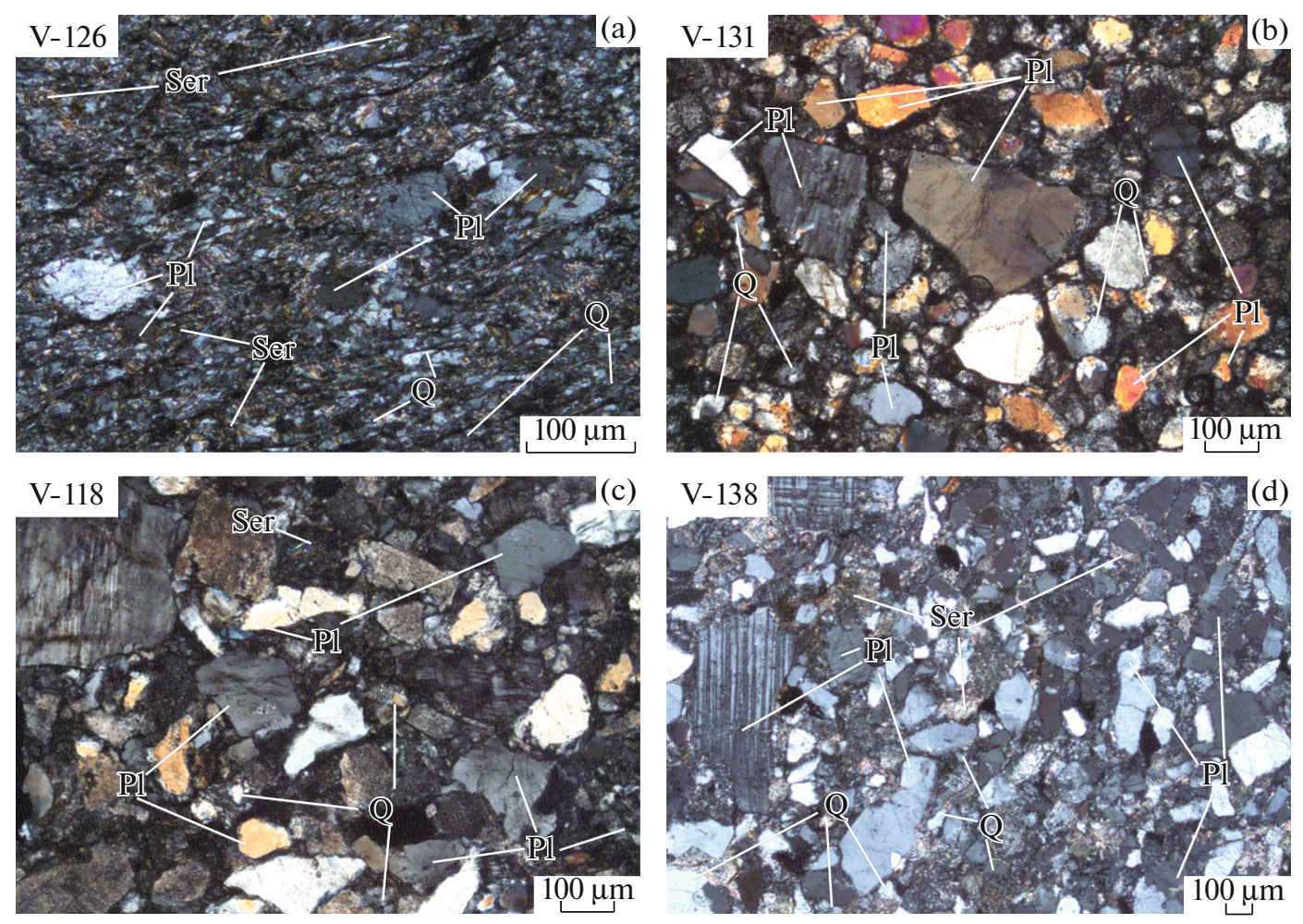

Fig. 3. Micrographs of samples (a) V-126, (b) V-131, (c) V-118, and (d) V-138. Indicated (abbreviations): Pl, plagioclase; Q, quartz; Ser, sericite.

In order to refine the geodynamics of the Galam Terrane, we carried out $\mathrm{U}-\mathrm{Pb}$ geochronological and $\mathrm{Lu}-\mathrm{Hf}$ isotope studies of detrital zircons from:

- metasiltstone of the Dzhyalak Formation (sample no. V-138);

- metasandstone of the Ir-Galam Formation (sample no. V-118);

- metasandstone of the Onnetock Formation (sample no. V-131);

- metasiltstone of the Akrinda Formation (sample no. V-126).

The sampling sites and micrographs of thin sections are shown in Figs. 1 and 3 and Table 1.

\section{ANALYTICAL METHODS \\ $U-P b$ Geochronological Studies}

Detrital zircons were isolated from metasedimentary rocks in the mineralogical laboratory of the Institute of Geology and Mineralogy, FEB RAS (Blagoveshchensk, Russia) using heavy liquids. Next, the zircons, together with standard zircons (FC, SL and R33), were mounted in an epoxy block and polished to expose mid-grain sections. The internal structure of zircon grains was studied in the CL and BSE modes using a Hitachi S-3400N scanning electron microscope (Hitachi High Technologies America Inc.) equipped with a Gatan Chroma CL2 detector (Gatan Inc., USA). Prior to isotope analyses, zircons were purified in an ultrasonic bath with $1 \% \mathrm{HNO}_{3}$ and $1 \% \mathrm{HCL}$ to remove any residual total lead from the surfaces of the zircons. U- $\mathrm{Pb}$ geochronological studies of zircons were carried out at the Geochronological Center of the University of Arizona (Arizona LaserChron Center, Tucson, Arizona, USA) using a Photon Machines Analyte G2 laser ablation system (Photon Machines Inc., USA) and an ICP Thermo Element 2 mass spectrometer (Thermo Fisher Scientific Inc., Germany). The crater diameter was $20 \mu \mathrm{m}$ and the depth was $15 \mu \mathrm{m}$. Calibration was done according to the FC standard (Duluth Complex, 1099.3 \pm 0.3 Ma [60]). Zircons SL (Sri Lanka) and R33 (Braintree complex) [43] as secondary standards for the control of measurements. The age values based on the ${ }^{206} \mathrm{~Pb} /{ }^{238} \mathrm{U}$ and ${ }^{207} \mathrm{~Pb} /{ }^{206} \mathrm{~Pb}$ ratios for the SL standard during measurements was $557 \pm 5$ and $558 \pm 7 \mathrm{Ma}(2 \sigma)$, respectively, which agrees well with the values obtained by G. Gehrels with the ID-TIMS method [48]. The average ages based on the ${ }^{206} \mathrm{~Pb} /{ }^{238} \mathrm{U}$ and ${ }^{207} \mathrm{~Pb} /{ }^{206} \mathrm{~Pb}$ ratios for the R33 standard were $417 \pm 7$ and $415 \pm 8 \mathrm{Ma}$, corresponding to the recommended ones $[43,56]$. Systematic errors are $0.9 \%$ for the ${ }^{206} \mathrm{~Pb} /{ }^{238} \mathrm{U}$ ratio and $0.8 \%$ for the ${ }^{206} \mathrm{~Pb} /{ }^{207} \mathrm{~Pb}$ ratio $(2 \sigma)$. Corrections for common $\mathrm{Pb}$ were introduced based on ${ }^{204} \mathrm{~Pb}$ corrected by ${ }^{204} \mathrm{Hg}$, in accordance with the model values. A detailed description of the analytical procedures is presented on the website of the University of Arizona Geochronological Center [87]. Concordant ages were calcu- 
Table 1. Determination of age, sampling site, and rock composition in samples (\%)

\begin{tabular}{|c|c|c|c|c|}
\hline Period (System) & Sample no. & GPS ( $\left.x^{\circ} x^{\prime} x^{\prime \prime}\right)$ & Formation & Rocks composition in samples \\
\hline \multicolumn{5}{|c|}{ Galam Terrane } \\
\hline Middle Devonian (?) & V-126 & $\begin{array}{l}134^{\circ} 29^{\prime} 37.4^{\prime \prime} \mathrm{E} \\
53^{\circ} 14^{\prime} 09.2^{\prime \prime} \mathrm{N}\end{array}$ & $\begin{array}{l}\text { Akrinda } \\
\text { Formation }\end{array}$ & $\begin{array}{l}\text { Gray schistose metasiltstones } \\
0.02-0.10 \text { mm, angular and subrounded: } \\
25-30 \% \text { quartz, } \\
8-10 \% \text { clastic rock, } \\
30-35 \% \text { plagioclase, } \\
10-15 \% \text { sericite }\end{array}$ \\
\hline Early Devonian (?) & V-131 & $\begin{array}{l}133^{\circ} 47^{\prime} 16.7^{\prime \prime} \mathrm{E} \\
53^{\circ} 45^{\prime} 02.7^{\prime \prime} \mathrm{N}\end{array}$ & $\begin{array}{l}\text { Onnetock } \\
\text { Formation }\end{array}$ & $\begin{array}{l}\text { Gray massive metasandstones } \\
0.15-0.20 \text { mm angular and subrounded: } \\
30-35 \% \text { quartz, } \\
7-9 \% \text { clastic rock, } \\
38-45 \% \text { plagioclase }\end{array}$ \\
\hline Early Devonian (?) & V-118 & $\begin{array}{r}132^{\circ} 38^{\prime} 30.0^{\prime \prime} \mathrm{E} \\
53^{\circ} 22^{\prime} 05.1^{\prime \prime} \mathrm{N}\end{array}$ & $\begin{array}{l}\text { Ir-Galam } \\
\text { Formation }\end{array}$ & $\begin{array}{l}\text { Gray massive metasandstones } \\
0.15-0.20 \text { mm angular and subrounded: } \\
20-25 \% \text { quartz, } \\
8-12 \% \text { debris, } \\
40-47 \% \text { plagioclase, } \\
2-3 \% \text { sericite }\end{array}$ \\
\hline Silurian (?) & V-138 & $\begin{array}{l}133^{\circ} 51^{\prime} 15.5^{\prime \prime} \mathrm{E} \\
54^{\circ} 00^{\prime} 43.9^{\prime \prime} \mathrm{N}\end{array}$ & $\begin{array}{l}\text { Dzhyalak } \\
\text { Formation }\end{array}$ & $\begin{array}{l}\text { Massive gray metasandstones } \\
0.15-0.20 \text { mm angular and subrounded: } \\
20-25 \% \text { quartz, } \\
8-10 \% \text { clastic rock, } \\
35-42 \% \text { plagioclase, } \\
5-7 \% \text { sericite }\end{array}$ \\
\hline
\end{tabular}

lated using Isoplot software (v. 3.6) [55, 68]. The following were excluded from the final age calculations:

- data for which it was impossible to calculate concordant ages;

- concordant ages that correspond to a $95 \%$ confidence level, but for which MSWD > 1;

$-{ }^{206} \mathrm{~Pb} /{ }^{238} \mathrm{U}$ and ${ }^{207} \mathrm{~Pb} /{ }^{235} \mathrm{U}$ ratios with errors $>3 \%$, since they exceed the accuracy of the LA-ICP-MS method.

The AgePick program [87] was used to calculate the values of the peaks on the age probability curves.

\section{Lu-Hf Isotope Studies of Zircons}

$\mathrm{Lu}-\mathrm{Hf}$ isotope analyses of zircons were performed at the University of Arizona Geochronological Center (Arizona LaserChron Center, Tucson, Arizona, USA) using a Nu High-Resolution Multi-Collector Induction-Coupled Plasma Mass Spectrometer (MC-ICPMS) (Nu Instruments, UK) and an Analyte G2 excimer laser (Teledyne CETAC, UK). Standard solutions JMC475, Spex Hf and Spex Hf, Yb and Lu, as well as standard zircons Mud Tank, 91500, Temora, R33, FC52, Plesovice and SL, were used to adjust and check the quality of analyses.
$\mathrm{Lu}-\mathrm{Hf}$ isotope analyses were performed at the same point as $\mathrm{U}-\mathrm{Pb}$ analyses. The laser beam diameter was $40 \mu \mathrm{m}$, the laser power was about $5 \mathrm{~J} / \mathrm{cm}^{2}$, the frequency was $7 \mathrm{~Hz}$, and the ablation rate was about $0.8 \mu \mathrm{m} / \mathrm{s}$. Details of the analytical methodology are presented on the website of the University of Arizona Geochronological Center [87].

To calculate $\varepsilon_{\mathrm{Hf}(\mathrm{t})}$ the decay constant ${ }^{176} \mathrm{Lu}(\lambda=$ $\left.1.867 \mathrm{e}^{-11}\right)$ was used after [63]. When calculating $\varepsilon_{\mathrm{Hf}(\mathrm{t})}$, the following chondrite ratios were used: ${ }^{176} \mathrm{Hf} /{ }^{177} \mathrm{Hf}$ (0.282785) and ${ }^{176} \mathrm{Lu} /{ }^{177} \mathrm{Hf}(0.0336)$ [45]. Crustal Hfmodel ages $\mathrm{t}_{\mathrm{Hf}(\mathrm{C})}$ were calculated by taking the average ratio ${ }^{176} \mathrm{Lu} /{ }^{177} \mathrm{Hf}$ in the continental crust of 0.0093 [42, 73]. To calculate the isotope parameters of the depleted mantle, the modern ratios ${ }^{176} \mathrm{Hf} /{ }^{177} \mathrm{Hf}=$ 0.28325 and ${ }^{176} \mathrm{Lu} /{ }^{177} \mathrm{Hf}=0.0384[44,64]$ were used.

\section{RESULTS \\ $U-P b$ Geochronological Studies}

The results of $\mathrm{U}-\mathrm{Pb}$ geochronological studies are given in Fig. 4 and Table S1 of Supplement 1. Cathodoluminescence (CL) images of individual detrital zircons from the youngest populations are shown in Fig. 5. 

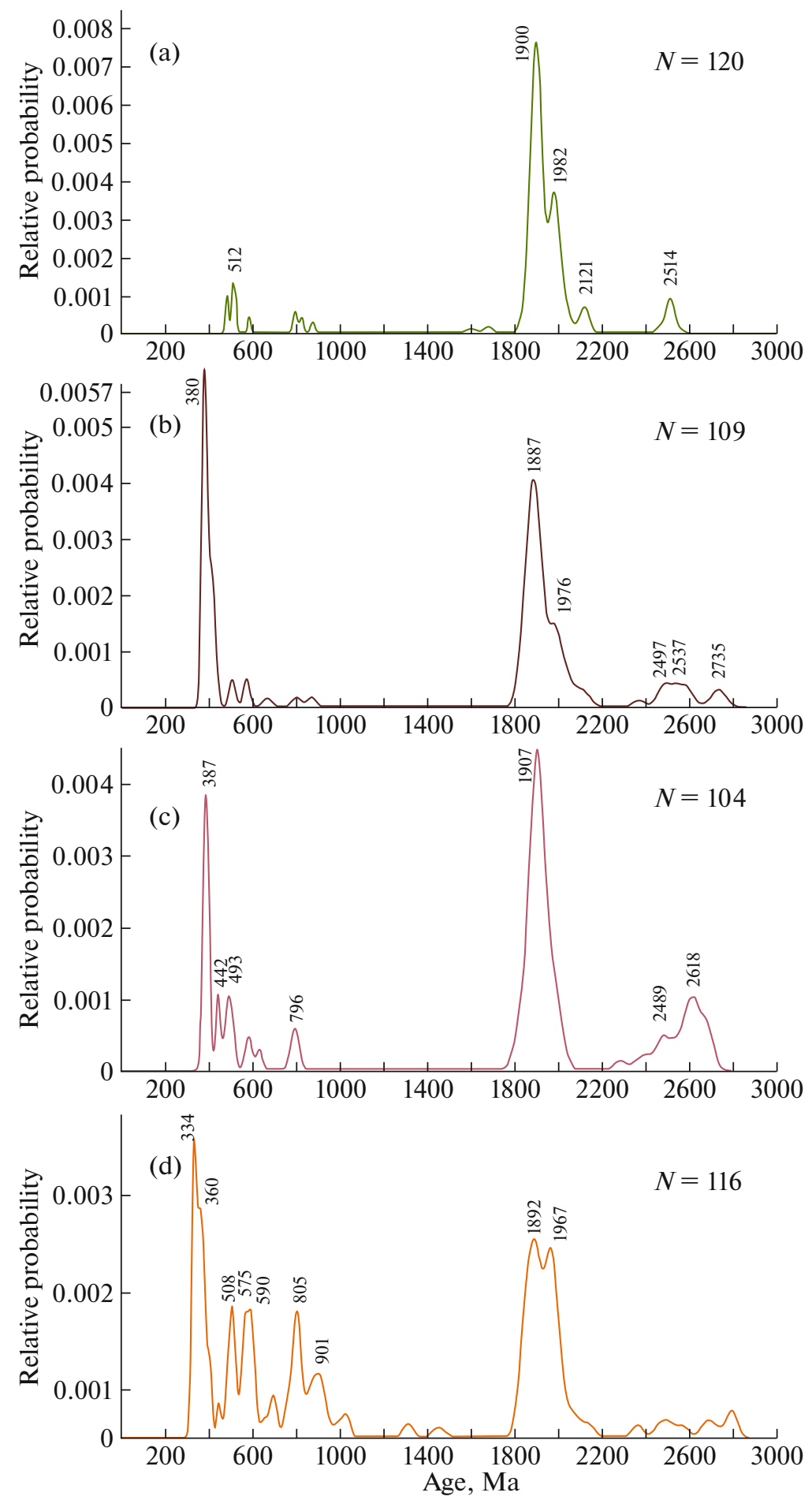

Fig. 4. Relative U-Pb age probability curves for detrital zircons from metasedimentary rocks of Galam Terrane. (a)-(d) samples: (a) V-138 (metasandstones of Dzhyalak Formation); (b) V-118 (metasandstones of Ir-Galam Formation); (c) V-131 (metasandstones of Onnetock Formation); (d) V-126 (metasiltstones of Akrinda Formation).

Sample V-138 (metasandstone of the Silurian Dzhyalak Formation (Fig. 3d; Table 1)). Of the 145 analyzed detrital zircons, a concordant age was obtained for 120 grains (Fig. 4a; Supplement 1: Table S1). Zircons are predominantly Paleoproterozoic (peaks on the age probability curve at 2121, 1982, and $1900 \mathrm{Ma})$, less often Archean (peak at $2514 \mathrm{Ma}$ ) and Early Paleozoic (peak at $512 \mathrm{Ma}$ ). In addition, there is an insignificant amount of Neoproterozoic zircons with ages of $877 \pm 5$, $827 \pm 5,798 \pm 8,797 \pm 4$, and $586 \pm 4$ Ma. The ages 

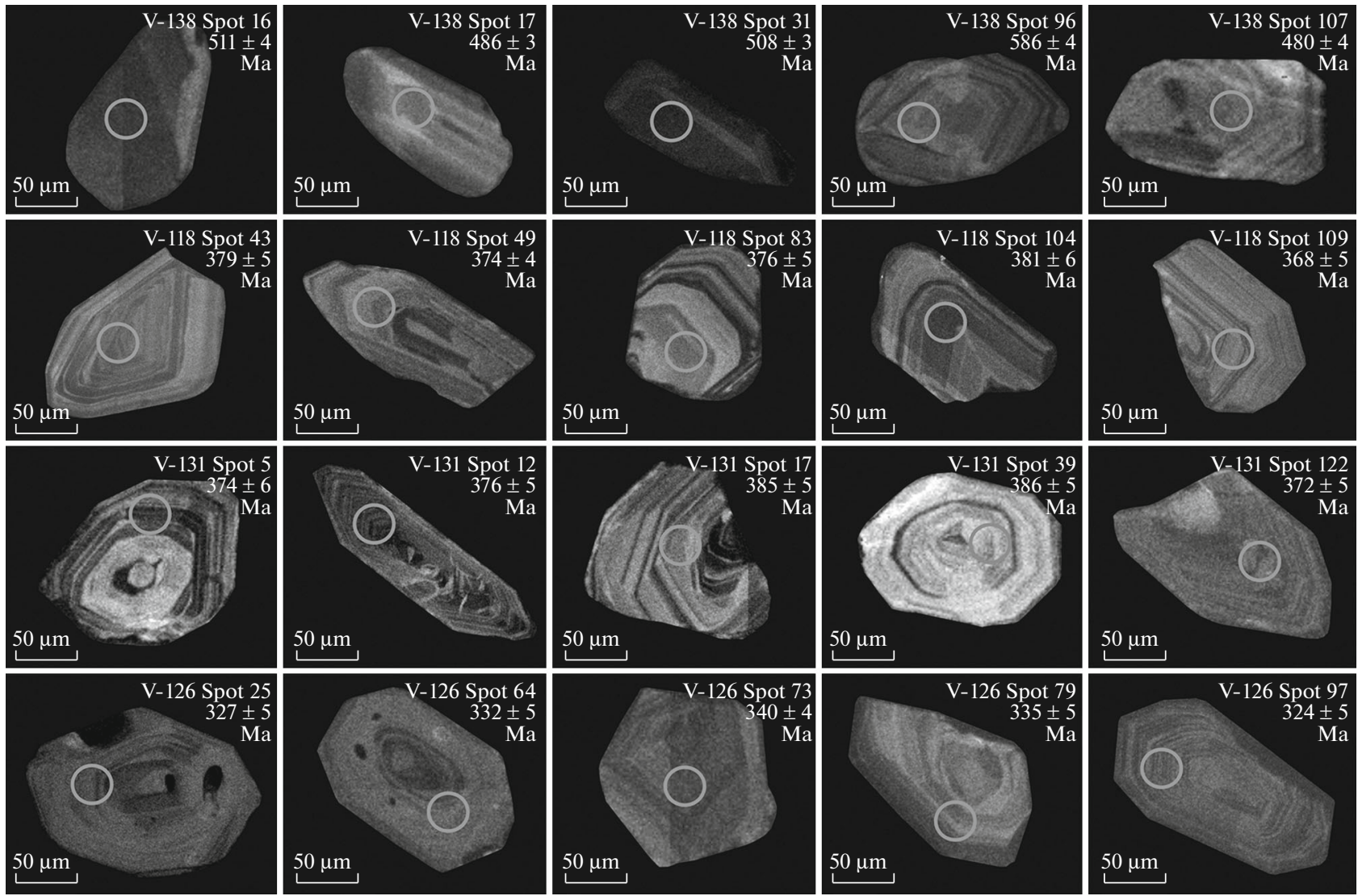

Fig. 5. Representative (CL) Images of detrital zircons from youngest populations from metasedimentary formation of the Galam Terrane.

of the youngest zircons are $511 \pm 4,508 \pm 3,486 \pm 3$, and $480 \pm 4 \mathrm{Ma}$, while the concordant age of the youngest group of three grains cannot be calculated.

Sample V-118 (metasandstone of Lower Devonian Ir-Galam Formation (Fig. 3c; Table 1)). One hundred nine concordant age estimates were obtained from 124 analyzed detrital zircons (Fig. 4b; Supplement 1: Table S1). Most of the grains are Paleoproterozoic (peaks on the probability age curve at 1976 and $1887 \mathrm{Ma}$ ) and Devonian (peak at $380 \mathrm{Ma}$ ). In addition, there are a number of Archean zircons (peaks at 2735 and $2537 \mathrm{Ma}$ ), as well as seven grains with concordant ages in the interval of 870-502 Ma. The concordant age of the youngest zircon is $368 \pm 5 \mathrm{Ma}$; the concordant age of the youngest group of three grains is $371 \pm 3$ Ma.

Sample V-131 (metasandstone of the Lower Devonian Onnetock Formation (Fig. 3b; Table 1)). Of the 120 analyzed grains of sample V-131, 104 concordant age estimates were obtained (Fig. 4c; Supplement 1: Table S1). The age of most grains are Archean (peak at 2618 and $2489 \mathrm{Ma}$ ), Paleoproterozoic (peak at $1907 \mathrm{Ma}$ ), and Paleozoic (peaks at 493, 442, and $387 \mathrm{Ma})$. Several Neoproterozoic zircons are present (peak at $796 \mathrm{Ma}$ ). The concordant age of the youngest zircon is $372 \pm 5 \mathrm{Ma}$, and the concordant age of the youngest group of three grains is $374 \pm 3 \mathrm{Ma}$.

Sample V-126 (metasiltstone of the Middle Devonian Akrinda Formation (Fig. 3a; Table 1)). A total of 128 detrital zircon grains from this sample were analyzed, of which concordant values were obtained for 116 grains (Fig. 4d; Supplement 1: Table S1). The overwhelming majority of zircons are Paleoproterozoic (the peaks on the probability age curve at 1967 and $1892 \mathrm{Ma}$ ), Neoproterozoic (peaks and 901, 805, 590 , and $575 \mathrm{Ma}$ ) and Paleozoic (peaks at 508, 360, and $334 \mathrm{Ma}$ ). The concordant age of the youngest zircon is $324 \pm 5 \mathrm{Ma}$; the concordant age of the youngest group of three grains is $378 \pm 3 \mathrm{Ma}$.

\section{Lu-Hf isotope studies of zircons}

The results of $\mathrm{Lu}-\mathrm{Hf}$ isotope studies of zircons are shown in Fig. 6 and Supplement 1: Table S2.

$\mathrm{Lu}-\mathrm{Hf}$ isotope studies were performed for:

- 22 zircon grains from metasiltstone (sample no. V-138) of the Silurian Dzhyalak Formation;

- 19 zircon grains from metasandstone (sample no. V-118) the Lower Devonian Ir-Galam Formation; 
-22 zircon grains from metasandstone (sample no. V-131) of the Lower Devonian Onnetock Formation;

- 20 zircon grains from metasiltstone (sample no. V-126) of the Middle Devonian Akrinda Formation.

According to the results obtained, Archean and Paleoproterozoic zircons have negative and weakly positive $\varepsilon_{\mathrm{Hf}(\mathrm{t})}$ values from -20.3 to +3.4 , and two-stage Hf-model ages $\left(\mathrm{t}_{\mathrm{Hf}(\mathrm{C})}\right)>2.2 \mathrm{Ga}$ (Fig. 6; Supplement 1: Table S2).

Neoproterozoic and Cambrian grains have higher $\varepsilon_{\mathrm{Hf}(\mathrm{t})}$ values from -5.2 to +11.5 and younger values of Hf-model ages $\mathrm{t}_{\mathrm{Hf}(\mathrm{C})}=1.61-1.01 \mathrm{Ga}$ (Fig. 6; Supplement 1: Table S2).

The $\varepsilon_{\mathrm{Hf(t)}}$ values and Hf-model ages of Ordovician, Silurian, Devonian and Carboniferous zircons are very different. They can be divided into two groups. The first is characterized by extremely negative $\varepsilon_{\mathrm{Hf}(\mathrm{t})}$ values from -33.0 to -12.1 with Archean and Paleoproterozoic model ages $\mathrm{t}_{\mathrm{Hf}(\mathrm{C})} 2.82-1.76 \mathrm{Ga}$. The second group is characterized by weakly negative and positive $\varepsilon_{\mathrm{Hf(t)}}$ values from -7.4 to +6.9 and younger (Mesoproterozoic-Neoproterozoic) model ages $\mathrm{t}_{\mathrm{Hf}(\mathrm{C})} 1.46-$ 0.90 Ga (Fig. 6; Supplement 1: Table S2).

\section{DISCUSSION}

\section{Sedimentation Boundary Conditions of the Galam Terrane}

Zircons, which make up the youngest age populations in the studied samples, have oscillatory zoning, indicating their magmatic origin (Fig. 5). In addition, these zircons are characterized by a $\mathrm{Th} / \mathrm{U}$ ratio of $1.1-$ 0.2 , which is also typical of magmatic zircons $[61,76]$.

The concordant age of the youngest zircon from metasiltstone (sample no. V-138) of the Dzhyalak Formation is $480 \pm 4 \mathrm{Ma}$, and the youngest peak on the age probability curve corresponds to $512 \mathrm{Ma}$ (Fig. 4a). These data indicate the age boundary of the deposits of this formation from Middle Cambrian to Early Ordovician. Thus, our results agree with the Silurian age of the Dzhyalak Formation, determined by the fossil fauna [20].

In metasandstone (sample no. V-118) of the IrGalam Formation, the concordant age of the youngest zircon is $368 \pm 5 \mathrm{Ma}$, and the youngest peak on the age probability curve corresponds to $380 \mathrm{Ma}$ (Fig. 4b). These data indicate that the lower sedimentation boundary of deposits of the Ir-Galam Formation is Late Devonian, which does not correspond to the age of this formation established from the fossil flora [20]. This could mean:

- there is a need to revise the age of the Ir-Galam Formation;

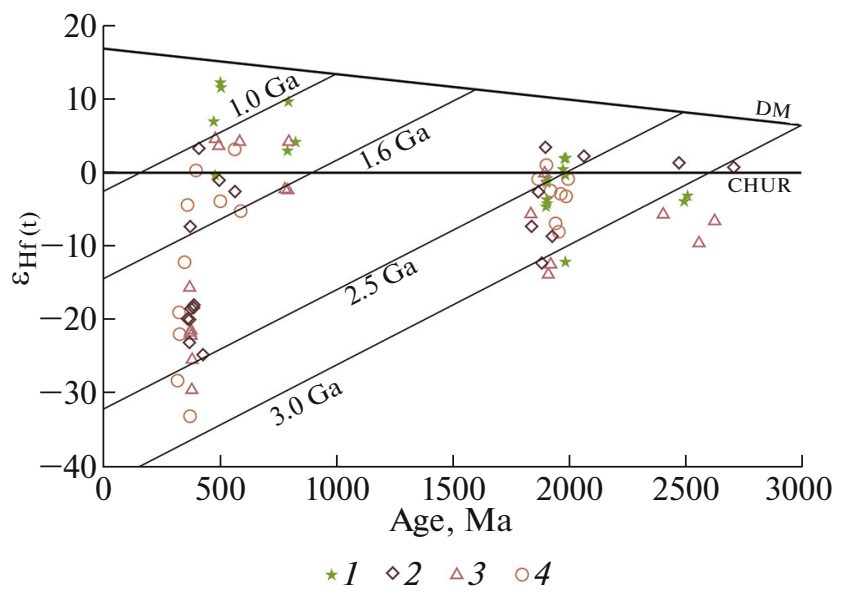

Fig. 6. Diagram of $\varepsilon_{\mathrm{Hf}(\mathrm{t})}$ age (Ma) for zircons from metasedimentary rocks of the Galam Terrane. 1-4, samples: 1, Dzhyalak Formation (sample no. V-138); 2, IrGalam Formation (sample no. V-118); 3, Onnetock Formation (sample no. V-131); 4, Akrinda Formation (sample no. V-126)

- the sample studied by us belongs to another (younger) thicker formation.

Currently, both causes are equally likely.

The concordant age of the youngest zircon from metasandstone (sample no. V-131) of the Onnetock Formation is $372 \pm 5 \mathrm{Ma}$, and the youngest peak on the age probability curve corresponds to $387 \mathrm{Ma}$ (Fig. 4c). These data indicate that the lower sedimentation boundary of these deposits is Middle Devonian. This contradicts the concept of the Early Devonian age of the Onnetok Formation, based on the finds of fossil flora [20], and can be explained by the same reasons given by us for the Ir-Galam Formation.

The youngest zircon from metasiltstone (sample no. V-126) of the Akrinda Formation has a concordant age of $324 \pm 5 \mathrm{Ma}$; the youngest peak on the relative age probability curve corresponds to $334 \mathrm{Ma}$ (Fig. 4d). These data determine the lower age boundary for the deposits of this formation as the Mississippian. However, this suite contains abundant marine fauna of the Middle Devonian [20]; therefore, sample V-126 probably belongs to a younger sedimentary formation.

\section{Characteristics of Provenance Areas of Detrital Material}

The eastern part of the Mongol-Okhotsk belt is located between the southeastern margin of the Siberian Craton and the Amur Superterrane, which are potential provenance areas of detrital material for sedimentary rocks in the Mongol-Okhotsk belt (Fig. 1). These provenance areas are characterized by sharply different age and isotope characteristics.

The southeastern frame of the Siberian Craton with the Early Precambrian basement is the source of both Early Precambrian and younger zircons with 
Early Precambrian Hf-model ages [1, 5, 9-14, 26, 31]. Conversely, the Amur Superterrane does not have an Early Precambrian basement and is composed of Neoproterozoic and Paleozoic and Early Mesozoic geological complexes $[24,25,35,37,58,65,77,80$, $83,84]$. Therefore, this is the provenance area of Neoproterozoic, Paleozoic and Early Mesozoic zircons with Neoproterozoic (less frequently-Mesoproterozoic) Hf-model age.

There is a third possible provenance area of detrital material: island arcs in the Mongol-Okhotsk Ocean. Their existence is presumed in most tectonic models of the evolution of this belt [33, 51, 71, 74, 75, 85]. It is possible that Paleozoic gabbro and plagiogranite bodies are the roots of such island arcs, but geochronological and $\mathrm{Hf}$ isotope data for these rocks are usually lacking.

Our $\mathrm{U}-\mathrm{Pb}$ geochronological data show that Paleoproterozoic zircons prevail in metasedimentary rocks of the Galam Terrane (Dzhyalak, Ir-Galam, Onnetock formations, and the Akrinda Formation), while Archean zircons are present in significant amounts (Figs. 4 and 6; Supplement 1: Table S1). These zircons are characterized by $\varepsilon_{\mathrm{Hf}(\mathrm{t})}$ values from -20.3 to +3.4 and model ages $t_{\mathrm{Hf}(\mathrm{C})}>2.2 \mathrm{Ga}$. The only provenance areas of such zircons in the region under consideration may be Paleoproterozoic and Archean magmatic and metamorphic complexes of the southeastern frame of the Siberian Craton [1, 5, 9-13, 16-18, 26, 28, 31].

Neoproterozoic and Cambrian zircons are quite rare in metasedimentary rocks of the Galam Terrane. These zircons have weaker negative and positive $\varepsilon_{\mathrm{Hf}(\mathrm{t})}$ values from -5.2 to +11.5 and fairly young model ages $t_{\mathrm{Hf}(\mathrm{C})} 1.61-1.01 \mathrm{Ga}$ (Fig. 6; Supplement 1: Table S2). Judging from the $\mathrm{Hf}$ isotope characteristics, island arcs could have been the source of these zircons. In particular, Cambrian $(511 \pm 3 \mathrm{Ma})$ plagiogranites of the Galam Terrane may be the root part of such an arc. This is confirmed by positive $\varepsilon_{\mathrm{Hf}(\mathrm{t})}$ values from +8.8 to +14.8 in zircons from these rocks [67].

Most of the Paleozoic zircons in metasedimentary rocks of the Galam Terrane are Devonian (samples V-118, V-126, and V-131) and Carboniferous (sample V-126) in age (Fig. 4; Supplement 1: Table S2). These zircons vary widely in the parameter $\varepsilon_{\mathrm{Hf}(\mathrm{t})}$ and the values of Hfmodel ages (Fig. 6; Supplement 1: Table S2). Zircons with negative $\varepsilon_{\mathrm{Hf}(\mathrm{t})}$ values from -33.0 to -12.1 and Archean/Paleoproterozoic model ages $t_{\mathrm{Hf}(\mathrm{C})}=2.82-$ $1.76 \mathrm{Ga}$ could have entered the sedimentation basin only from the southern margin of the Siberian Craton. Such sources could have been the following:

- granitoids of the Olekma Complex with ages of $358 \pm 6 \mathrm{Ma}[30]$ and $360 \pm 2 \mathrm{Ma}$ [12];

- granitoids of the Barguzin complex with an age of 330-310 Ma [38, 40].

- volcanic rocks of the Amazar-Gilyui zone with an age of $358 \pm 2 \mathrm{Ma}[38,40]$.
The source of the Late Devonian zircons is unclear, but they may be intrusions of the Krestovsky and Kruchinin complexes [41].

Another group of Devonian and Carboniferous zircons is characterized by weakly negative and positive $\varepsilon_{\mathrm{Hf}(\mathrm{t})}$ values from -7.4 to +6.9 and younger (Mesoproterozoic-Neoproterozoic) ages $t_{\mathrm{Hf}(\mathrm{C})} 1.46-0.90 \mathrm{Ga}$ (Fig. 6; Supplement 1: Table S2). The Hf isotope composition of these zircons suggests an origin of rocks without significant involvement of Early Precambrian crust in the sources of primary melts. Thus, this source cannot be located within the margin of the Siberian Craton. Consequently, these sources can be island arcs of the Mongol-Okhotsk Ocean, or complexes of the Amur Superterrane. Available paleomagnetic data indicate a large distance in the Paleozoic between the Siberian Craton and the continental massifs combined in the Amur Superterrane, which excludes the simultaneous influx of detrital material from the Siberian Craton and Amur Superterrane in the Paleozoic [51-53, $57,72,78,79,81]$. Consequently, the island arcs of the Mongol-Okhotsk Ocean can be considered the main provenance areas of Devonian and Carboniferous zircons with $\varepsilon_{\mathrm{Hf}(\mathrm{t})}$ values from -7.4 to +6.9 and Mesoproterozoic/Neoproterozoic Hf-model ages. Currently, there is no evidence of Devonian and Carboniferous island arcs in the eastern part of the Mongol-Okhotsk belt. However, it is possible that tonalites with an age of $392 \pm 18 \mathrm{Ma}$ are examples of such arcs [67].

Thus, our data suggest that the detrital material for the metasedimentary rocks of the Galam Terrane came mainly from the southeastern (in modern coordinates) margin of the Siberian Craton, as well as from the island arcs of the Mongol-Okhotsk Ocean.

\section{TECTONIC IMPLICATION}

Based on structural studies, B.A. Natal'in and L.I. Popeko [32] showed that the Galam Terrane is a Mesozoic accretionary complex of the Siberian Craton, which explains the close spatial association of rocks of different origin (cherts, limestones, basalts, and sandstones).

Based on our $\mathrm{U}-\mathrm{Pb}$ geochronological and $\mathrm{Lu}-\mathrm{Hf}$ isotope-geochemical data for detrital zircons, it follows that the main provenance areas of detrital material for metasedimentary rocks of the Galam Terrane were located in the southeastern margin of the Siberian Craton. The geological material supplied by the island arcs of the Mongol-Okhotsk Paleocean accumulated to a much lesser extent. Our data additionally confirm that the Galam Terrane is an accretionary complex (or part of it) formed in the frontal part of the southeastern margin of the Siberian Craton.

In determining the formation age of the Galam accretionary complex, the following conditions were taken into account [12, 30, 38-40]: 


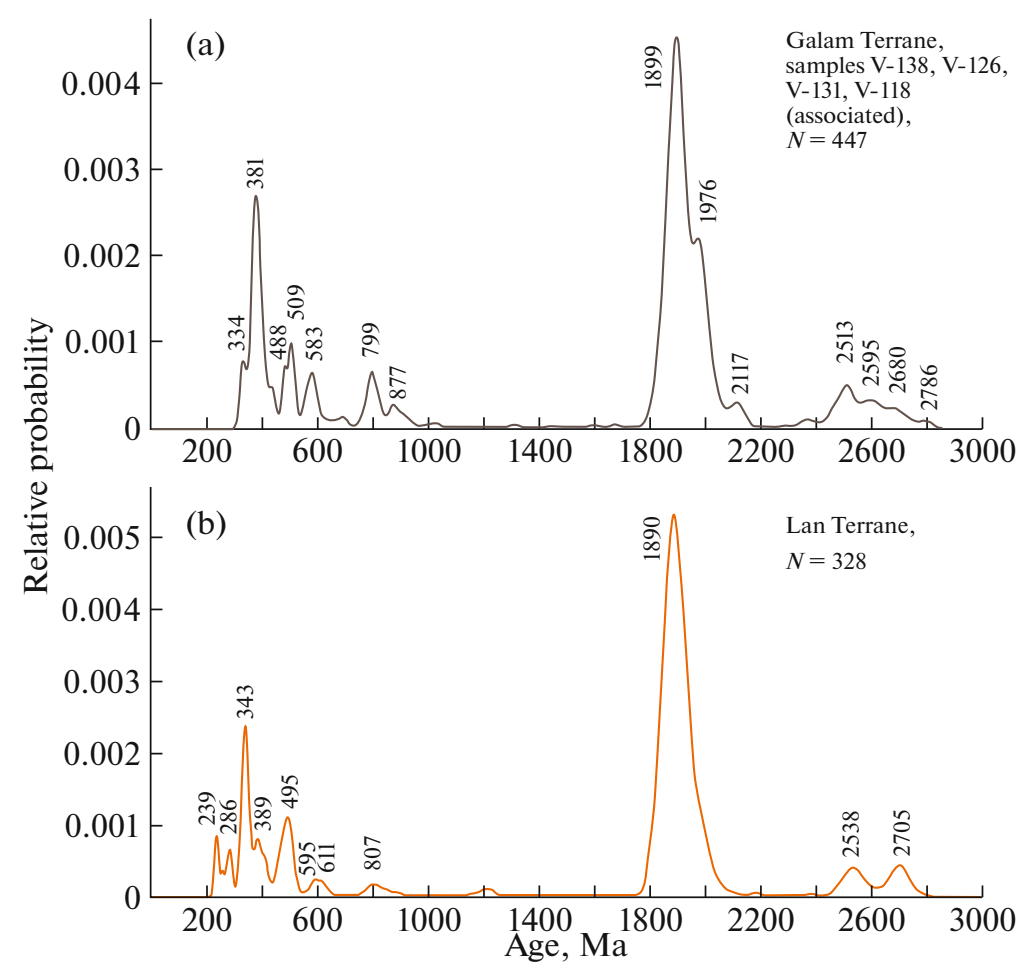

Fig. 7. Relative $\mathrm{U}-\mathrm{Pb}$ age probability curves for detrital zircons from metasedimentary rocks of (a) Galam Terrane versus age determination of zircons from rocks of (b) Lan Terrane (according to obtained data with use of data from [21]).

- The Galam Terrane consists mainly of Silurian, Devonian, and Early Carboniferous formations;

- Permian sedimentary complexes are poorly developed and can possibly be attributed to later evolution of the Mongol-Okhotsk Ocean;

- along the southern and southeastern margins of the Siberian Craton, granitoids and volcanic rocks

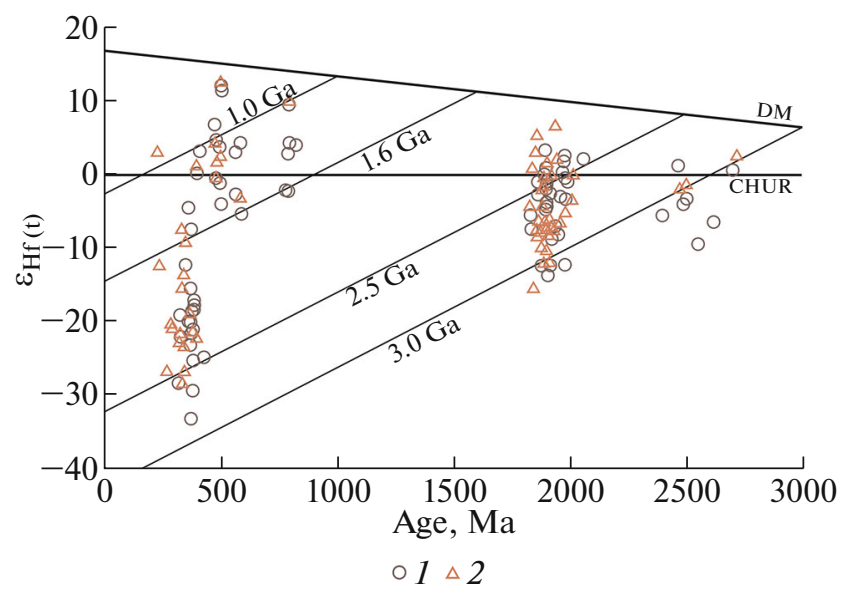

Fig. 8. Diagram of $\varepsilon_{\mathrm{Hf}(\mathrm{t})}$ age (Ma) for zircons from metasedimentary rocks of (a) Galam Terrane versus age determinations of zircons from rocks of (b) Lan Terrane (after [21]). 1-2, terranes: 1, Galam; 2, Lan.
(Late Devonian and Early Carboniferous) are widespread, probably associated with subduction under this margin.

Based on these data, we believe that the Galam accretionary complex is Late Paleozoic in age. However, this does not exclude the possibility that younger accretion complexes were also present along the southern margin of the Siberian Craton. In particular, the Lan Terrane is a Mesozoic accretionary complex, which consists of Late Paleozoic and Early Mesozoic formations [21] (Fig. 1). The plots of the relative ages probability curves of zircons from metasedimentary rocks of the Lan and Galam terranes, as well as the Hf isotope composition of these zircons, approach each other (Figs. 7a, 7b, 8). However, the metasedimentary rocks of the Lan terrane contain younger zircons than those in the Galam Terrane. Thus, the results of analyzing the isotope composition of zircons may indicate the existence of Paleozoic and Mesozoic subduction zones under the southern and southeastern margins of the Siberian Craton (in modern coordinates).

We cannot ignore the fact that A.I. Khanchuk's model [15, 51], which assumes that the Galam Terrane is a displaced fragment of the Okhotsk-Koryak orogenic belt, reconstructs geological processes with a high degree of reliability, but at first glance, this model contradicts the results of our studies. However, we consider it important to emphasize that the Khanchuk's research objects were the Cambrian complexes, 
while the objects of this study were Silurian, Devonian, and Carboniferous (?) metasedimentary complexes. Therefore, it can be suggested that the Cambrian and younger complexes have different tectonic natures and represent different tectonic plates combined in the modern structure of the Galam Terrane.

\section{CONCLUSIONS}

The data obtained and results of the research led to the following conclusions:

(1) In the studied Ir-Galam, Onnetock, and Akrinda formations, the age of the sedimentation boundary based on $\mathrm{U}-\mathrm{Pb}$ dating of detrital zircons proved younger than the age established from fossil fauna.

(2) Detrital zircons in metasedimentary rocks of the Galam Terrane contain a large number of Archean and Paleoproterozoic zircons. In addition, most zircons, regardless of age, have predominantly negative $\varepsilon_{\mathrm{Hf}(\mathrm{t})}$ values from -30.0 to -10.0 and $\mathrm{Hf}$-model ages $t_{\mathrm{Hf(C)}}>2.2$ billion years. These data suggest that the main provenance areas of detrital material for metasedimentary rocks of the Galam Terrane were located in the southeastern margin of the Siberian Craton.

(3) The influx of Devonian and Carboniferous detrital zircons with weakly negative and positive $\varepsilon_{\mathrm{Hf}(\mathrm{t})}$ values from -7.4 to +6.9 and younger model ages $t_{\mathrm{Hf}(\mathrm{C})}=1.46-0.90 \mathrm{Ga}$ occurred due to the breakup of island arcs in the Mongol-Okhotsk Ocean.

(4) The Galam Terrane is a Paleozoic accretionary complex (or part of it) at the southeastern margin of the Siberian Craton.

\section{ACKNOWLEDGMENTS}

The authors are grateful to E.N. Voropaev (Institute of Geology and Nature Management (IGNM FEB RAS, Blagoveshchensk, Russia), O.G. Medvedev (IGNM FEB RAS, Blagoveshchensk, Russia) for preparation of zircon monofractions. The authors are grateful to colleagues of the University of Arizona Geochronological Center (Arizona LaserChron Center, Tucson, Arizona, USA) for conducting analytical research. The authors sincerely thank entrepreneur and pilot A.N. Luchnikov (Blagoveshchensk, Russia) for providing a helicopter and flights to the hard-toreach study area, on which this study fully depended.

The authors thank the reviewers, Acad. V.V. Yarmolyuk (IGEM RAS, Moscow, Russia) and Prof. A.K. Khudoley (St. Petersburg State University-Institute of Physics of the Earth, St. Petersburg, Russia), as well as M.N. Shupletsova (GIN RAS, Moscow, Russia) for preparing the original article.

\section{FUNDING}

The research was supported by the Russian Science Foundation (project no. 18-17-00002).

\section{CONFLICT OF INTEREST}

The authors declare that they have no conflicts of interest.

\section{SUPPLEMENTARY INFORMATION}

The online version contains supplementary material available at https://doi.org/10.1134/S001685212106008X.

\section{ADDITIONAL INFORMATION}

The publication of this Open Access article was funded by Pleiades Publishing.

\section{OPEN ACCESS}

This article is licensed under a Creative Commons Attribution 4.0 International License, which permits use, sharing, adaptation, distribution and reproduction in any medium or format, as long as you give appropriate credit to the original author(s) and the source, provide a link to the Creative Commons license, and indicate if changes were made. The images or other third party material in this article are included in the article's Creative Commons license, unless indicated otherwise in a credit line to the material. If material is not included in the article's Creative Commons license and your intended use is not permitted by statutory regulation or exceeds the permitted use, you will need to obtain permission directly from the copyright holder. To view a copy of this license, visit http://creativecommons.org/licenses/by/4.0/.

\section{REFERENCES}

1. I. V. Buchko, E. B. Sal'nikova, A. B. Kotov, A. M. Larin, S. D. Velikoslavinskii, A. A. Sorokin, A. P. Sorokin, and S. Z. Yakovleva, "Paleoproterozoic gabbroanorthosites of the Selenga-Stanovoi superterrane, southern framing of the Siberian Craton," Dokl. Earth Sci. 407, 372-375 (2006). https://doi.org/10.1134/S1028334X06030068

2. I. V. Buchko, A. E. Izokh, E. B. Sal'nikova, A. A. Sorokin, A. B. Kotov, and S. Z. Yakovleva, "Petrology of the Late Jurassic ultramafic-mafic Veselki Massif, southeastern framing of the Siberian Craton," Petrology 15 (3), 264-274 (2007).

3. I. V. Buchko, A. A. Sorokin, E. B. Sal'nikova, A. B. Kotov, A. M. Larin, A. E. Izokh, S. D. Velikoslavinskii, and S. Z. Yakovleva, "The Late Jurassic age and geochemistry of ultramafic-mafic massifs of the SelengaStanovoy superterrane (southern framing of the North Asian Craton)," Russ. Geol. Geophys. 48 (12), 10261036 (2007).

4. I. V. Buchko, A. A. Sorokin, A. E. Izokh, A. M. Larin, A. B. Kotov, E. B. Sal'nikova, S. D. Velikoslavinskii, A. P. Sorokin, S. Z. Yakovleva, and Yu. V. Plotkina, "Petrology of the Early Mesozoic ultramafic-mafic Luchina massif (southeastern periphery of the Siberian craton)," Russ. Geol. Geophys. 49 (8), 570-581 (2008).

5. I. V. Buchko, A. A. Sorokin, E. B. Sal'nikova, A. B. Kotov, A. M. Larin, A. P. Sorokin, S. D. Velikoslavinskii, and S. Z. Yakovleva, "Age and tectonic setting of the Kengurak-Sergachi gabbro-anorthosite massif (the 
Selenga-Stanovoi superterrane, southern frame of the Siberian Craton)," Stratigr. Geol. Correl. 16 (4), 349359 (2008).

6. I. V. Buchko, A. A. Sorokin, E. B. Sal'nikova, A. B. Kotov, S. D. Velikoslavinskii, A. M. Larin, A. E. Izokh, and S. Z. Yakovleva, "Triassic stage of mafic magmatism in the Dzhugdzhur-Stanovoi Superterrane (southern framework of the North Asian Craton)," Russ. Geol. Geophys. 51 (11), 1157-1166 (2010).

7. I. V. Buchko, A. A. Sorokin, E. B. Sal'nikova, A. B. Kotov, A. M. Larin, S. D. Velikoslavinskii, A. P. Sorokin, and Yu. V. Plotkina, "High-titanium gabbroids of the western Dzhugdzhur-Stanovoy superterrane: Age and tectonic setting," Geochem. Int., 48 (6), 617-620 (2010).

8. I. V. Buchko, A. A. Sorokin, A. B. Kotov, A. V. Samsonov, Yu. O. Larionova, V. A. Ponomarchuk, and A. M. Larin, "The age and tectonic setting of the Lukinda dunite-gabbro-anorthosite massif in the east of the Selenga-Stanovoi superterrane, Central Asian Fold Belt,” Russ. Geol. Geophys. 59 (7), 709-717 (2018).

9. S. D. Velikoslavinskii, A. B. Kotov, E. B. Sal'nikova, A. M. Larin, A. A. Sorokin, A. P. Sorokin, V. P. Kovach, E. V. Tolmacheva, and B. M. Gorokhovskii, "Age of Ilikan Sequence from the Stanovoi complex of the Dzhugdzhur-Stanovoi superterrane, Central-Asian Foldbelt,” Dokl Earth Sci. 438 (1), 612-616 (2011).

10. S. D. Velikoslavinskii, A. B. Kotov, E. B. Sal'nikova, A. M. Larin, A. A. Sorokin, A. P. Sorokin, V. P. Kovach, E. V. Tolmacheva, S. Z. Yakovleva, and I. V. Anisimova, "Age of the Ust'-Gilyui Sequence in the Stanovoi complex of the Selenga-Stanovoi superterrain, Central Asian Fold Belt," Dokl Earth Sci. 444 (4), 661-665 (2012).

11. S. D. Velikoslavinskii, A. B. Kotov, V. P. Kovach, A. A. Sorokin, A. P. Sorokin, E. V. Tolmacheva, K. L. Wang, and S. L. Cung, "The Paleoproterozoic age of protoliths of metasedimentary rocks of the Sutam formation of the Aldan granulite-gneiss megacomplex (Stanovoi suture)," Dokl Earth Sci. 463 (2), 765-769 (2015).

12. S. D. Velikoslavinskii, A. B. Kotov, V. P. Kovach, E. V. Tolmacheva, A. M. Larin, A. A. Sorokin, A. P. Sorokin, K. L. Wang, and E. B. Sal'nikova, "Age, sources, and provenances of protoliths of metasedimentary rocks of the Dzheltulak Group, Dzheltulak suture," Dokl Earth Sci. 468 (2), 545-548 (2016).

13. S. D. Velikoslavinskii, A. B. Kotov, V. P. Kovach, A. M. Larin, A. A. Sorokin, A. P. Sorokin, E. V. Tolmacheva, E. B. Sal'nikova, K. L. Wang, B. M. Jahn, and S. L. Cung, "Mesozoic age of the Gilyui Metamorphic Complex in the junction zone of the Selenga-Stanovoi and Dzhugdzhur-Stanovoi superterranes, Central Asian fold belt,” Dokl Earth Sci. 468 (2), 561-565 (2016).

14. S. D. Velikoslavinskii, A. B. Kotov, V. P. Kovach, E. V. Tolmacheva, A. A. Sorokin, E. B. Sal'nikova, A. M. Larin, N. Yu. Zagornaya, K. L. Wang, and S.-L. Chung, Age and tectonic position of the Stanovoi metamorphic complex in the eastern part of the Central Asian Foldbelt," Geotectonics 51 (4), 341-352 (2017).

15. Geodynamics, Magmatism, and Metallogeny of the Russian East, Ed. by A. I. Khanchuk (Dalnauka, Vladivostok, 2006), Book 1 [in Russian].
16. V. A. Glebovitsky, I. S. Sedova, D. I. Matukov, S. L. Presnyakov, N. G. Berezhnaya, E. V. Tolmacheva, L. M. Samorukova, and S. A. Sergeev, "Age of the Stanovoy Complex of east Siberia: Evidence from SHRIMP II ion microprobe data," Dokl Earth Sci. 412 (1), 35-38 (2007).

17. V. A. Glebovitsky, I. S. Sedova, N. G. Berezhnaya, S. L. Presnyakov, and L. M. Samorukova, "Age of migmatites in the Stanovoi Complex, east Siberia: Results of zircon dating by the SHRIMP II U-Pb method," Dokl Earth Sci. 420 (1), 542-546 (2008).

18. V. A. Glebovitsky, A. B. Kotov, E. B. Sal'nikova, A. M. Larin, and S. D. Velikoslavinskii, "Granulite complexes of the Dzhugdzhur-Stanovoi Fold Region and the Peristanovoi Belt: Age, formation conditions, and geodynamic settings of metamorphism," Geotectonics 43 (4), 253-263 (2009).

19. T. V. Donskaya, D. P. Gladkochub, A. M. Mazukabzov, B. De Waele, and S. L. Presnyakov, "The Late Triassic Kataev volcanoplutonic association in western Transbaikalia, a fragment of the active continental margin of the Mongol-Okhotsk Ocean," Russ. Geol. Geophys. 53 (1), 22-36 (2012).

20. V. Yu. Zabrodin, V. A. Guryanov, C. G. Kislyakov, N. A. Kremenitskaya, A. V. Makhinin, and E. S. Opalikhina, The 1: 1000000 State Geological Map of the Russian Federation. Ser. Far Eastern. Sheet N-53 (Shantary Islands), Ed. by G. V. Roganov (Vseross. NauchnoIssled. Geol. Inst., St. Petersburg, 2007). http://webmapget.vsegei.ru/index.html (Accessed June 23, 2021).

21. V. A. Zaika and A. A. Sorokin, "Ages and sources of sedimentary rocks of the Lan terrane in the MongolOkhotsk Fold Belt: Results of zircon $\mathrm{U}-\mathrm{Pb}$ and $\mathrm{Lu}-\mathrm{Hf}$ isotope studies," Russ. J. Pac. Geol. 14 (3), 193-205 (2020). https://doi.org/10.1134/S1819714020030070

22. V. A. Zaika, A. A. Sorokin, B. Syu, A. B. Kotov, and V. P. Kovach, "Geochemical features and sources of metasedimentary rocks of the western part of the Tukuringra Terrane of the Mongol-Okhotsk Fold Belt," Stratigr. Geol. Correl. 26 (2), 157-178 (2018).

23. V. D. Kozlov, S. V. Efremov, S. I. Dril', and G. P. Sandimirova, "Geochemistry, isotopic geochronology, and genesis of the Verkhnyaya Unda granitoid batholith," Geochem. Int. 41 (4), 364-378 (2003).

24. A. B. Kotov, A. A. Sorokin, E. B. Sal'nikova, A. P. Sorokin, A. M. Larin, S. D. Velikoslavinskii, T. V. Belyakova, I. V. Anisimova, and S. Z. Yakovleva, "Mesozoic age of granitoids from the Beket Complex (Gonzha Block within the Argun terrane of the Central Asian Fold Belt)," Dokl Earth Sci. 429 (2), 1457-1461 (2009).

25. A. B. Kotov, A. M. Mazukabzov, T. M. Skovitina, S. D. Velikoslavinskii, A. A. Sorokin, and A. P. Sorokin, "Structural evolution and geodynamic position of the Gonzha Block, Upper Amur Region," Geotectonics 47 (5), 351-361 (2013).

26. A. B. Kotov, S. D. Velikoslavinskii, V. P. Kovach, A. A. Sorokin, A. P. Sorokin, T. M. Skovitina, N. Yu. Zagornaya, K.-L. Wang, S.-L. Chung, and B.-M. Jahn, "Paleoproterozoic age of the Zeya Group, Stanovoy Complex of the Dzhugdzhur-Stanovoy Superterrane (Central Asian mobile belt): Results of 
$\mathrm{Sm}-\mathrm{Nd}$ isotopic and $\mathrm{U}-\mathrm{Th}-\mathrm{Pb}$ geochronological (LA-ICP-MS) analyses," Dokl. Earth Sci. 471 (2), 1234-1237 (2016).

27. A. M. Larin, A. B. Kotov, E. B. Sal'nikova, A. A. Sorokin, A. P. Sorokin, A. M. Korshunov, S. D. Velikoslavinskii, S. Z. Yakovleva, and Yu. V. Plotkina, "Age and tectonic position of granites and volcanics in the eastern margin of the Selenga-Vitim volcano-plutonic belt," Dokl Earth Sci. 441 (1), 1502-1507 (2011).

28. A. M. Larin, A. B. Kotov, S. D. Velikoslavinskii, E. B. Sal'nikova, and V. P. Kovach, "The Early Precambrian A-type granites of the Aldan shield and its folded frame: sources and geodynamic settings," Petrology 20 (3), 218-239 (2012).

29. A. M. Larin, A. B. Kotov, E. B. Sal'nikova, S. D. Velikoslavinskii, A. A. Sorokin, A. P. Sorokin, S. Z. Yakovleva, and I. V. Anisimova, "Granitoids of the Tukuringra complex in the Selenga-Stanovoi superterrane of the Central Asian mobile belt: Age and geodynamic setting," Dokl Earth Sci. 457 (2), 945-949 (2014).

30. A. M. Larin, A. B. Kotov, V. P. Kovach, E. B. Sal'nikova, V. V. Yarmolyuk, S. D. Velikoslavinskii, S. Z. Yakovleva, and $\mathrm{Yu}$. V. Plotkina, "Granitoids of the Olekma Complex in the Selenga-Stanovoi superterrane of the central Asian mobile belt: Age and tectonic position," Dokl Earth Sci. 464 (1), 903-906 (2015).

31. A. M. Larin, A. B. Kotov, E. B. Sal'nikova, V. P. Kovach, G. V. Ovchinnikova, V. M. Savatenkov, S. D. Velikoslavinskii, A. A. Sorokin, I. M. Vasil'eva, N. A. Sergeeva, N. N. Mel'nikov, K.-L. Wang, and S.-L. Chung, "Granitoids of the Pozdnestanovoy Complex of the Dzhugdzhur-Stanovoy Superterrane, Central Asia Fold Belt: Age, tectonic setting, and sources," Petrology 26 (5), 447-468 (2018).

32. B. A. Natal'in and L. I. Popeko, "The Paleozoic of the Galam segment, Mongol-Okhotsk fold system," Tikhookean. Geol., No. 2, 81-89 (1991) [in Russian].

33. L. M. Parfenov, L. I. Popeko, and O. Tomurtogoo, "Problems of tectonics of the Mongol-Okhotsk orogenic belt," Geol. Pac. Ocean, 16 (5), 797-830 (2001).

34. E. B. Sal'nikova, A. M. Larin, A. B. Kotov, A. P. Sorokin, A. A. Sorokin, S. D. Velikoslavinskii, S. Z. Yakovleva, A. M. Fedoseenko, and Yu. V. Plotkina, "The Toksko-Algomin igneous complex of the Dzhugdzhur-Stanovoi Folded Region: Age and geodynamic setting," Dokl Earth Sci. 409 (2), 888-892 (2006).

35. E. B. Sal'nikova, A. B. Kotov, V. P. Kovach, S. D. Velikoslavinskii, B.-M. Jahn, A. A. Sorokin, A. P. Sorokin, K. L. Wang, S. L. Chung, H. Y. Lee, and E. V. Tolmacheva, "Age of the Gonzha Group (Argun Terrane, Central Asian Fold Belt) inferred from U-Pb and $\mathrm{Lu}-$ Hf zircon data," Dokl Earth Sci. 444 (5), 692-695 (2012).

36. A. N. Serezhnikov and Yu. R. Volkova, The 1: 1000000 State Geological Map of the Russian Federation. Ser. Far Eastern. Sheet N-52 (Zeya), Ed. by A. S. Volsky (Vseross. Nauchno-Issled. Geol. Inst., St. Petersburg, 2007). http://webmapget.vsegei.ru/index.html (Accessed June 23, 2021).

37. Yu. N. Smirnova, A. A. Sorokin, L. I. Popeko, A. B. Kotov, and V. P. Kovach, "Geochemistry and provenances of the Jurassic terrigenous rocks of the
Upper Amur and Zeya-Dep troughs, eastern Central Asian fold belt," Geochem. Int. 55 (2), 163-183 (2017).

38. A. A. Tsygankov, D. I. Matukov, N. G. Berezhnaya, A. N. Larionov, V. F. Pocokhov, B. Ts. Tsyrenov, A. A. Khromov, and S. A. Sergeev, "Late Paleozoic granitoids in western Transbaikalia: Sequence of formation, sources of magmas, and geodynamics," Russ. Geol. Geophys., 48 (1), 120-140 (2007).

39. A. A. Tsygankov, B. A. Litvinovsky, B. Jahn, M. Reichow, D. Y. Liu, A. N. Larionov, S. L. Presnyakov, E. N. Lepekhina, and S. A. Sergeev, "Sequence of magmatic events in the Late Paleozoic of Transbaikalia, Russia (U-Pb isotope data)," Russ. Geol. Geophys. 51 (9), 972-994 (2010).

40. A. A. Tsygankov, "Late Paleozoic granitoids in western Transbaikalia: Sequence of formation, sources of magmas, and geodynamics," Russ. Geol. Geophys. 55 (2), 153-176 (2014).

41. E. A. Shivokhin, A. F. Ozerskii, A.V. Kurilenko, N. I. Raitina, and V. V. Karasev, The 1: 1000000 State Geological map of the Russian Federation. Ser. AldanTransbaikalian. Sheet M-50 (Borzya), Ed. by V. V. Starshenko (Vseross. Nauchno-Issled. Geol. Inst., St. Petersburg, 2010). http://webmapget.vsegei.ru/index.html (Accessed June 6, 2021).

42. Y. Amelin and W. J. Davis, "Geochemical test for branching decay of ${ }^{176} \mathrm{Lu}$," Geochim. Cosmochim. Acta 69, 465-473 (2005). https://doi.org/10.1016/j.gca.2004.04.028

43. L. P. Black, S. L. Kamo, C. M. Allen, D. W. Davis, J. N. Aleinikoff, J. W. Valley, R. Mundil, I. H. Campbell, R. J. Korsch, I. S. Williams, and C. Foudoulis, "Improved ${ }^{206} \mathrm{~Pb} /{ }^{238} \mathrm{U}$ microprobe geochronology by the monitoring of trace-element-related matrix effect; SHRIMP, ID-TIMS, ELA-ICP-MS and oxygen isotope documentation for a series of zircon standards," Chem. Geol. 205, 15-140 (2004).

https://doi.org/10.1016/j.chemgeo.2004.01.003

44. J. Blichert-Toft and F. Albarede, "The Lu-Hf isotope geochemistry of chondrites and the evolution of the mantle-crust system," Earth Planet. Sci. Lett. 148 (12), 243-258 (1997). https://doi.org/10.1016/S0012-821X(97)00040-X

45. A. Bouvier, J. D. Vervoort, and J. Patchett, "The Lu$\mathrm{Hf}$ and $\mathrm{Sm}-\mathrm{Nd}$ isotopic composition of CHUR: Constraints from unequilibrated chondrites and implications for the bulk composition of terrestrial planets," Earth Planet. Sci. Lett. 273, 48-57 (2008). https://doi.org/10.1016/j.eps1.2008.06.010

46. D. Bussien, N. Gombojav, W. Winkler, and A. Quadt, "The Mongol-Okhotsk Belt in Mongolia-An appraisal of the geodynamic development by the study of sandstone provenance and detrital zircons," Tectonophysics 510, 132-150 (2011).

https://doi.org/10.1016/j.tecto.2011.06.024

47. T. V. Donskaya, D. P. Gladkochub, A. M. Mazukabzov, and A. V. Ivanov, "Late Paleozoic-Mesozoic subduction-related magmatism at the southern margin of the Siberian Continent and the 150-million-year history of the Mongolia-Okhotsk Ocean," J. Asian Earth Sci. 62, 79-97 (2013).

https://doi.org/10.1016/j.jseaes.2012.07.023 
48. G. E. Gehrels, V. Valencia, and J. Ruiz, "Enhanced precision, accuracy, efficiency, and spatial resolution of $\mathrm{U}-\mathrm{Pb}$ ages by laser ablation-multicollector-inductively coupled plasma-mass spectrometry," Geochem. Geophys. Geosyst. 9, 1-13 (2008).

https://doi.org/10.1029/2007GC001805

49. H. Hara, T. Kurihara, K. Tsukada, Y. Kon, T. Uchino, T. Suzuki, M. Takeuchi, Y. Nakane, M. Nuramkhaan, and Chuluun Minjin, "Provenance and origins of a Late Paleozoic accretionary complex within the Khangai-Khentei Belt in the Central Asian Orogenic Belt, Central Mongolia,” J. Asian Earth Sci. 75, 141-157 (2013). https://doi.org/10.1016/j.jseaes.2013.07.019

50. T. K. Kelty, A. Yin, B. Dash, and E. Gehrels George, and E. Ribeiro Angela, Detrital-zircon geochronology of Paleozoic sedimentary rocks in the Hangay-Hentey Basin, North-Central Mongolia: Implications for the tectonic evolution of the Mongol-Okhotsk Ocean in Central Asia," Tectonophysics 451, 290-311 (2008). https://doi.org/10.1016/j.tecto.2007.11.052

51. A. I. Khanchuk, A. N. Didenko, L. I. Popeko, A. A. Sorokin, and B. F. Shevchenko, "Structure and evolution of the Mongol-Okhotsk orogenic belt. The Central Asian orogenic belt geology," in Evolution, Tectonics, and Models, Ed. by A. Kröner (Borntraeger Sci. Publ., Stuttgart, Germany, 2015), pp. 211-234.

52. V. A. Kravchinsky, J.-P. Cogne, W. P. Harbert, and M. I. Kuzmin, "Evolution of the Mongol-Okhotsk Ocean as constrained by new palaeomagnetic data from the Mongol-Okhotsk Suture Zone, Siberia," Geophys. J. Int. 148, 34-57 (2002a). https://doi.org/10.1046/j.1365-246x.2002.01557.x

53. V. A. Kravchinsky, A. A. Sorokin, and V. Courtillot, "Paleomagnetism of Paleozoic and Mesozoic sediments from the southern margin of Mongol-Okhotsk Ocean, Far Eastern Russia,” J. Geophys. Res. Atmos. 107, 1-22 (2002b).

https://doi.org/10.1029/2001JB000672

54. H. Liu, Y. Li, H. He, P. Huangfu, and Y. Liu, "Twophase southward subduction of the Mongol-Okhotsk Oceanic Plate constrained by Permian-Jurassic granitoids in the Erguna and Xing'an massifs (NE China)," Lithos 304-307, 347-361 (2018).

https://doi.org/10.1016/j.lithos.2018.01.016

55. K. R. Ludwig, User's manual for a geochronological toolkit for Microsoft Excel, (Berkeley Geochron. Center Spec. Publ., UK, 2008), pp. 1-75. https://drive. google.com/file/d/15UcAyMSrm5EWRbia2_nYMmoHa7fvSJc_view (Accessed December 24, 2020).

56. J. M. Mattinson, "Analysis of the relative decay constants of ${ }^{235} \mathrm{U}$ and ${ }^{238} \mathrm{U}$ by multi-step CA-TIMS measurements of closed system natural zircon samples," Chem. Geol. 275, 186-198 (2010). https://doi.org/10.1016/j.chemgeo.2010.05.007

57. D. V. Metelkin, V. A. Vernikovsky, A. Y. Kazansky, and M. T. Wingate, "Late Mesozoic tectonics of Central Asia based on paleomagnetic evidence," Gondwana Res. 18, 400-419 (2010). https://doi.org/10.1016/j.gr.2009.12.008

58. L. Miao, F. Zhang, M. Zhu, and D. Liu, "Zircon SHRIMP U-Pb dating of metamorphic complexes in the conjunction of the Greater and Lesser Xing'an
Ranges, NE China: Timing of formation and metamorphism and tectonic implications," J. Asian Earth Sci. 114, 634-648 (2015).

https://doi.org/10.1016/j.jseaes.2014.09.035

59. B. A. Natal'in, "History and modes of Mesozoic accretion in Southeastern Russia," Island Arc 2, 15-34 (1993).

60. J. B. Paces and J. D. Miller, "Precise U-Pb ages of Duluth Complex and related mafic intrusions, Northeastern Minnesota: Geochronological insights to physical, petrogenic, paleomagnetic, and tectonomagmatic processes associated with the $1.1 \mathrm{Ga}$ midcontinent rift system,” J. Geophys. Res.: Solid Earth 98, 13997-14013 (1993). https://doi.org/10.1029/93JB01159

61. D. Rubatto, "Zircon trace element geochemistry: Partitioning with garnet and the link between $\mathrm{U}-\mathrm{Pb}$ ages and metamorphism," Chem. Geol. 184, 123-138 (2002). https://doi.org/10.1016/S0009-2541(01)00355-2

62. D. Ruppen, A. Knaf, D. Bussien, W. Winkler, A. Chimedtseren, and A. von Quadt, Restoring the Silurian to Carboniferous northern active continental margin of the Mongol-Okhotsk Ocean in Mongolia: Hangay-Hentey accretionary wedge and seamount collision," Gondwana Res. 25, 1517-1534 (2014). https://doi.org/10.1016/j.gr.2013.05.022

63. E. Scherer, C. Münker, and K. Mezger, "Calibration of the lutetium-hafnium clock," Science 293, 683-687 (2001). https://doi.org/10.1126/science.1061372

64. U. Söderlund, P. J. Patchett, J. D. Vervoort, and C. E. Isachsen, "The ${ }^{176} \mathrm{Lu}$ decay constant determined by $\mathrm{Lu}-\mathrm{Hf}$ and $\mathrm{U}-\mathrm{Pb}$ isotope systematics of Precambrian mafic intrusions," Earth Planet. Sci. Lett. 219, 311324 (2004). https://doi.org/10.1016/S0012-821X(04)00012-3

65. A. A. Sorokin, R. O. Ovchinnikov, W. L. Xu, V. P. Kovach, H. Yang, A. B. Kotov, V. A. Ponomarchuk, A. V. Travin, and Yu. V. Plotkina, "Ages and nature of the protolith of the Tulovchikha metamorphic complex in the Bureya Massif, Central Asian Orogenic Belt, Russia: Evidence from U-Th- Pb, Lu- $\mathrm{Hf}, \mathrm{Sm}-\mathrm{Nd}$, and ${ }^{40} \mathrm{Ar} /{ }^{39} \mathrm{Ar}$ Data," Lithos 332-333, 340-354 (2019). https://doi.org/10.1016/j.lithos.2019.03.001

66. A. A. Sorokin, V. A. Zaika, V. P. Kovach, A. B. Kotov, W. Xu, and H. Yang, "Timing of closure of the Eastern Mongol-Okhotsk Ocean: Constraints from $\mathrm{U}-\mathrm{Pb}$ and Hf isotopic data of detrital zircons from metasediments along the Dzhagdy Transect," Gondwana Res. 81, 5878 (2020). https://doi.org/10.1016/j.gr.2019.11.009

67. A. A. Sorokin, V. A. Zaika, N. M. Kudryashov, "Timing of formation and geodynamic setting of Paleozoic granitoids in the Eastern Mongol-Okhotsk Belt: Constraints from geochemical, U-Pb and Hf isotope data," Lithos 388-389, 106086 (2021). https://doi.org/10.1016/j.lithos.2021.106086

68. C. J. Spencer, C. L. Kirkland, and R. J. M. Taylor, "Strategies towards statistically robust interpretations of in situ U-Pb zircon geochronology," Geosci. Front. 7, 581-589 (2016). https://doi.org/10.1016/j.gsf.2015.11.006

69. D. Y. Sun, J. Gou, T. H. Wang, Y. S. Ren, Y. J. Liu, H. Y. Guo, X. M. Liu, and Z. C. Hu, "Geochronolog- 
ical and geochemical constraints on the Erguna Massif basement, NE China-Subduction history of the Mongol-Okhotsk Oceanic Crust," Int. Geol. Rev. 55, 1801-1816 (2013). https://doi.org/10.1080/00206814.2013.804664

70. J. Tang, W. L. Xu, F. Wang, S. Zhao, and W. Wang, "Mesozoic southward subduction history of the Mongol-Okhotsk Oceanic Plate: Evidence from geochronology and geochemistry of Early Mesozoic intrusive rocks in the Erguna Massif, NE China," Gondwana Res. 31, 218-240 (2016). https://doi.org/10.1016/j.gr.2014.12.010

71. O. Tomurtogoo, B. F. Windley, A. Kroner, G. Badarch, and D. Y. Liu, "Zircon age and occurrence of the Adaatsag Ophiolite and Muron Shear Zone, Central Mongolia: Constraints on the evolution of the Mongol-Okhotsk Ocean, suture and orogeny," J. Geol. Soc. London 162 (1), 125-134 (2005). https://doi.org/10.1144/0016-764903-146

72. R. Van der Voo, D. J. van Hinsbergen, M. Domeier, W. Spakman, and T. H. Torsvik, "Latest Jurassic-earliest Cretaceous closure of the Mongol-Okhotsk Ocean: A paleomagnetic and seismological-tomographic analysis," in Late Jurassic Margin of Laurasia-A Record of Faulting, Accommodating, Plate Rotation. GSA Spec. Pap. Vol. 513, Ed. by T. H. Anderson, A. N. Didenko, C. L. Johnson, A. I. Khanchuk, and J. H. MacDonald (Geol. Soc. Am., 2015), pp. 589-606.

73. J. D. Vervoort and P. J. Patchett, "Behavior of hafnium and neodymium isotopes in the crust: Constraints from Precambrian crustally derived granites," Geochim. Cosmochim. Acta 60, 3717-3723 (1996). https://doi.org/10.1016/0016-7037(96)00201-3

74. T. Wang, Y. Tong, L. Zhang, S. Li, H. Huang, J. Jianjun Zhang, L. Guo, Q. Yang, D. Hong, T. Donskaya, D. Gladkochub, and N. Tserendash, "Phanerozoic granitoids in the central and eastern parts of Central Asia and their tectonic significance," J. Asian Earth Sci. 145, 368-392 (2017). https://doi.org/10.1016/j.jseaes.2017.06.029

75. W. Wang, J. Tang, W. L. Xu, and F. Wang, "Geochronology and geochemistry of Early Jurassic volcanic rocks in the Erguna Massif, Northeast China: Petrogenesis and implications for the tectonic evolution of the Mongol-Okhotsk suture belt," Lithos 218-219, 73-86 (2015).

https://doi.org/10.1016/j.lithos.2015.01.012

76. I. S. Williams, "Response of detrital zircon and monazite, and their $\mathrm{U}-\mathrm{Pb}$ isotopic systems, to regional metamorphism and host-rock partial melting, Cooma Complex, Southeastern Australia," Aust. J. Earth Sci. 48, 557-580 (2001). https://doi.org/10.1046/j.1440-0952.2001.00883.x

77. G. Wu, Y. C. Chen, Y. J. Chen, and Q. T. Zeng, "Zircon $\mathrm{U}-\mathrm{Pb}$ ages of the metamorphic supracrustal rocks of the Xinghuadukou Group and granitic complexes in the Argun Massif of the Northern Great Hinggan
Range, NE China, and their tectonic implications," J. Asian Earth Sci. 49, 214-233 (2012).

https://doi.org/10.1016/j.jseaes.2011.11.023

78. L. Wu, V. A. Kravchinsky, and D. K. Potter, "Absolute reconstruction of the closing of the Mongol-Okhotsk Ocean in the Mesozoic elucidates the genesis of the slab geometry underneath Eurasia," J. Geophys. Res.: Solid Earth 122 (7), 4831-4851 (2017). https://doi.org/10.1002/2017JB014261

79. L. Wu, V. A. Kravchinsky, and D. K. Potter, "Apparent polar wander paths of the major Chinese blocks since the Late Paleozoic: Toward restoring the amalgamation history of East Eurasia,” Earth Sci. Rev. 171, 492-519 (2017).

https://doi.org/10.1016/j.earscirev.2017.06.016

80. M. J. Xu, W. L. Xu, F. Wang, and F. H. Gao, "Age, association and provenance of the "Neoproterozoic" Fengshuigouhe Group in the Northwestern Lesser Xing'an Range, NE China: Constraints from zircon U-Pb geochronology," J. Earth Sci. 23, 786-801 (2012).

https://doi.org/10.1007/s12583-012-0291-0

81. P. Zhao, Y. Chen, B. Xu, M. Faure, G. Shi, and F. Choulet, "Did the Paleo-Asian Ocean between North China block and Mongolia Block exist during the Late Paleozoic? First paleomagnetic evidence from central-eastern Inner Mongolia, China,” J. Geophys. Res.: Solid Earth 118 (5), 1873-1894 (2013).

https://doi.org/10.1002/jgrb.50198

82. P. Zhao, B. Xu, and B. Jahn, "The Mongol-Okhotsk Ocean subduction-related Permian peraluminous granites in Northeastern Mongolia: Constraints from zircon $\mathrm{U}-\mathrm{Pb}$ ages, whole-rock elemental and $\mathrm{Sr}-\mathrm{Nd}-$ Hf isotopic compositions," J. Asian Earth Sci. 144, 225-242 (2017).

https://doi.org/10.1016/j.jseaes.2017.03.022

83. J. B. Zhou and S. A. Wilde, "The crustal accretion history and tectonic evolution of the NE China segment of the Central Asian Orogenic Belt," Gondwana Res. 23, 1356-1377 (2013). https://doi.org/10.1016/j.gr.2012.05.012

84. J. B. Zhou, S. A. Wilde, X. Z. Zhang, S. M. Ren, and C. Q. Zheng, "Early Paleozoic metamorphic rocks of the Erguna Block in the Great Xing'an Range, NE China: Evidence for the timing of magmatic and metamorphic events and their tectonic implications," Tectonophysics 499, 105-117 (2011).

https://doi.org/10.1016/j.tecto.2010.12.009

85. L. P. Zonenshain, M. I. Kuzmin, and L. M. Natapov, "Geology of the USSR: A plate tectonic synthesis," AGU Bull. Ser.: Geodynam. 21, 1-242 (1990).

86. International Chronostratigraphic Chart (2018). https:// stratigraphy.org/chart (Accessed December 20, 2020).

87. Arizona Laserchron Center. www.sites.google.com/a/ laserchron.org/laserchron/ (Accessed August 21, 2021). 